\title{
The value of discretion in Africa: Evidence from acquired intangible assets under IFRS $3^{*}$
}

\author{
Abongeh A. Tunyi \\ Sheffield University Management School \\ University of Sheffield, United Kingdom \\ a.tunyi@sheffield.ac.uk
}

\author{
Dimu Ehalaiye \\ School of Accountancy, Massey Business School \\ Massey University, New Zealand \\ o.ehalaiye@massey.ac.nz \\ Ernest Gyapong \\ College of Business \\ Zayed University, United Arab Emirates \\ Ernest.gyapong@zu.ac.ae
}

\section{Collins G. Ntim ${ }^{\dagger}$}

Centre for Research in Accounting, Accountability and Governance (CRAAG)

Department of Accounting

Southampton Business School

University of Southampton, United Kingdom

C.G.Ntim@soton.ac.uk.

December 7, 2019

${ }^{*}$ We thank Paul Chaney (the Editor) and two anonymous reviewers for many valuable suggestions. We also benefited from comments made by conference participants at the British Accounting \& Finance Association (BAFA) Emerging Markets SIG meetings at Sheffield (2018) and Prague (2019), as well as seminar participants at the School of Accounting and Commercial Law, Victoria University of Wellington (2018). We acknowledge financial support from the University of Sheffield and the School of Accountancy, Massey University.

${ }^{\dagger}$ Corresponding author 


\begin{abstract}
The paper examines the value of managerial discretion in financial reporting by exploring the value relevance of intangible assets acquired in business combinations (AIA) before and after the 2008 International Financial Reporting Standard (IFRS) 3 amendment. The 2008 IFRS 3 amendment gave managers the discretion to recognize previously unrecognized intangibles in the target firm, hence, we posit that if managerial discretion improves the quality of financial reporting, we should observe an increase in the value relevance of AIA after the amendment. Our empirical analysis is based on a dataset of 603 mergers announced between 2004 to 2016, across 7 African countries. Consistent with our main hypothesis, we find that the value relevance of AIA, predominantly acquired goodwill (AGW), increased after the amendment, suggesting that managerial discretion improves the quality of financial information. Importantly, we highlight a caveat to this argument by showing that the value of discretion is moderated by the underlying institutional quality, with the value relevance of AIA being greater in high-quality institutional contexts. Our findings are robust to alternative measures of AIA, alternative models for testing value relevance and various controls for endogeneity. Overall, our findings have important implications for accounting standard-setters, governments, investors and practitioners.
\end{abstract}

Keywords: Managerial discretion, IFRS 3, acquired intangible assets, business combinations, institutional quality, Africa. 


\section{Introduction}

Financial reporting standards, whether based on generally accepted accounting principles (GAAP) or international financial reporting standards (IFRS), are characterised by a multiplicity of financial reporting choices ${ }^{1}$ that provide managers with some discretion to exercise judgement when preparing financial statements (Perotti \& Windisch, 2017; Tucker \& Zarowin, 2006). The moral hazard associated with the separation of ownership from control in modern corporations (Hambrick \& Abrahamson, 1995; Sirén et al., 2018) can be exacerbated if managers exercise this discretion in an opportunistic rather than an efficient manner (Bowen et al., 2008; Hadani et al., 2015). Despite the associated moral hazard, managerial discretion offers several benefits, particularly in the area of financial reporting (Demski et al., 1984; Morck et al., 1990). For instance, Verrecchia (1986) argues that managerial discretion may permit managers to choose reporting options that legitimately reduce corporate tax liability and regulatory costs, and hence, increase firm value. Importantly, financial markets rely on information in financial reports (Verrecchia, 1986). Thus, the flexibility inherent in managerial discretion over accounting policy choices can improve the price formation process by allowing managers to convey relevant private information about their firm to investors (Holthausen \& Watts, 2001; Kothari, 2001; Perotti \& Windisch, 2017).

Consequently, a number of empirical studies (Bowen et al., 2008; Perotti \& Windisch, 2017; Subramanyam, 1996; Tucker \& Zarowin, 2006) have examined whether managerial discretion relating to financial reporting alternatives are value relevant. For example, Tucker \& Zarowin (2006) report that managerial discretion relating to accruals improves the informativeness of future earnings. Similarly, Subramanyam (1996) and Perotti \& Windisch (2017) find that managerial discretion in relation to accruals is positively associated with informational efficiency, whilst Bowen et al. (2008) report that increased accounting discretion arising from poor governance practices impacts positively on future

\footnotetext{
${ }^{1}$ Examples include accruals, asset impairment and amortization, stock valuation and treatment of manufacturing costs.
} 
returns. Discernibly, these studies have not only examined a limited number of financial reporting choice (e.g., accruals) often with mixed results (e.g., Dechow et al., 2010; Holthausen \& Watts, 2001; Kothari, 2001; Verrecchia, 2001), but also mainly focused on developed countries (e.g., UK and US), and thereby arguably impairing a complete understanding of the value relevance of managerial discretion relating to financial reporting choices.

Thus, our study broadly seeks to contribute to the literature by exploring whether managers exercise discretion in financial reporting in an opportunistic or efficient manner by identifying the conditions under which managerial discretion improves financial reporting or not. Specifically, we deviate from the literature which largely draws evidence from accruals (Dechow et al., 2010; Holthausen \& Watts, 2001; Kothari, 2001; Perotti \& Windisch, 2017; Subramanyam, 1996; Verrecchia, 2001) by examining evidence relating to the reporting of intangibles acquired during business combinations - acquired intangible assets $(\mathrm{AIA})^{2}$. Further, while prior research largely focuses on the relationship between managerial discretion and (internal) corporate governance quality (Bowen et al., 2008; Gong et al., 2016), we explore how the quality of a firm's (external) institutional environment may impact opportunistic behaviour associated with managerial discretion.Specifically, we argue that, besides internal corporate governance systems (Bowen et al., 2008; Dong \& Gou, 2010), strong external institutions can play an important role by incentivising managers to use their discretion to improve the quality of reported financial information (efficient manner) rather than to extract private benefits (opportunistic manner).

In recent years, corporate intangibles have become more important in financial reporting due to significant growth in information technology and the resulting development of technology-related assets. The debate on the value relevance of intangible assets stems from the fact that, unlike other physical assets, intangible assets are largely knowledgebased assets without physical substance and thus, are usually unique to firms (Basu \&

\footnotetext{
${ }^{2}$ Acquired intangible assets (AIA) refer to intangible assets acquired during business combinations. We also use the phrases; 'business combinations', and 'mergers and acquisitions', interchangeably.
} 
Waymire, 2008; Skinner, 2008). ${ }^{3}$ Valuing such assets, particularly those acquired from other firms (including intangible assets that may previously have been unrecognized by these acquiree or target firms) as required by IFRS 3, poses a challenge. This challenge is partly due to the existence of information asymmetry between the acquirer and target firms during business combinations. This, therefore, represents one aspect of financial reporting for which managerial discretion in financial reporting might be critical. Although accounting standard-setters (particularly, the International Accounting Standards Board, IASB) have responded to this challenge with several amendments to existing standards, little is known about the effects of these amendments ${ }^{4}$ on the value relevance of AIA. The 2008 IFRS 3 amendment, in particular, afforded acquiring managers the discretion to recognize previously unrecognized intangibles in the target or acquiree firm, yet it is unclear whether this additional managerial discretion has improved the informativeness of reported values. We, therefore, examine the importance of managerial discretion in this novel setting by testing whether the amendment improved the informativeness of AIA.

Additionally, the influence of the underlying institutional environment on the consequences of managerial discretion in financial reporting also remains unexplored. This is, perhaps, due to the fact that prior studies exploring managerial discretion tend to focus on a single country context, mainly the US (Bowen et al., 2008; Perotti \& Windisch, 2017; Tucker \& Zarowin, 2006). These studies (e.g. Bowen et al., 2008; Dong \& Gou, 2010) consider the influences of internal firm-level corporate governance factors on managerial discretion, but ignore the influence of external institutions. Our study thus contributes to the existing literature by addressing this research gap. Specifically, we adopt a crosscountry approach that allows us to explore the importance of the underlying institutional quality (IQ), which varies across countries. Besides the advantage of generating more

\footnotetext{
${ }^{3}$ That is, there are usually no suitable comparators trading outside the firm in arms-length transactions.

${ }^{4}$ The limited number of studies that exist in this area have focused on goodwill impairments and their implications, as well as the post-acquisition firm performance effects of AIA (Hamberg \& Beisland, 2014; Hamberg et al., 2011; Su \& Wells, 2015), rather than the value relevance of the acquirers' total intangible assets, which often include both goodwill and other acquired intangible assets.
} 
generalisable results, a cross-country approach can produce more powerful statistical results by exploiting time-series, as well as cross-sectional variations at both the firm- and country-levels.

The African continent, in particular, presents an interesting setting to examine the value relevance of managerial discretion relating to AIA for a number of reasons. First, over the last decade, Africa has experienced increased growth in mergers and acquisitions (M\&As) activities (Mergermarket, 2016; Tunyi \& Ntim, 2016). According to Thomson Reuters database, since 1999, Africa has doubled its share of global M\&As, resulting in about $\$ 35$ and $\$ 25$ billion in announced deals in 2014 and 2016 alone, respectively (Thomson Reuters, 2014, 2016). This surge in M\&A deals is expected to continue (Ellis et al., 2015; Mergermarket, 2016). Second, despite the wide convergence of IFRS around the world, debates persist on its relevance to developing countries (particularly, those in Africa), as they are often underlined by weak institutions and enforcement mechanisms that can impact negatively on the effectiveness of IFRS adoption. Amongst the 6 continents for which World Governance Indicator data is available ${ }^{5}$, Africa reports the lowest aggregate level of IQ. ${ }^{6}$ Nonetheless, as shown in Table 1, even within Africa, the levels of IQ differ markedly across countries. This allows us to contribute to the literature by exploring the extent to which relatively strong external institutions play a role in ensuring that managers use their discretion to improve the quality of reported financial information.

Our paper makes three distinct contributions. Firstly, we develop and propose a simple framework to estimate AIA for a large sample of firms. Our framework extracts AIA from time series data relating to total intangibles. The alternative to estimating AIA from reported intangibles is the use of merger premiums, as in Su \& Wells (2015) or relying on hand-collected data from notes to financial statements. This new framework

\footnotetext{
${ }^{5}$ World Governance Indicators (WGI) are provided by Kaufmann et al. (2010) and is freely obtainable from the World Bank Database. The data used covers the period from 2004 to 2016. We discuss this data in more detail in the data section of the study.

${ }^{6}$ By our estimates, between 2004 and 2016, the average WGI is -0.672 for Africa, -0.354 for Asia, -0.041 for South America, 0.232 for Oceania, 0.422 for North America and 0.764 for Europe.
} 
should, thus, support further research on AIA under IFRS 3.

Secondly, we document the importance of managerial discretion in financial reporting by exploring the value relevance of AIA before and after the 2008 IFRS 3 amendment. The 2008 IFRS 3 amendment afforded managers the discretion to recognize previously unrecognized intangible assets by the acquired firms. We find that AIA was not value relevant before the 2008 amendment, but was value relevant after the amendment, suggesting that investors appear to value, in particular, the managerial discretion offered to acquirers under the 2008 IFRS 3 amendment, to recognize AIA not previously recognized by target firms.

Thirdly, our African setting characterised by institutional voids and generally weak IQ presents a unique environment to explore how the underlying institutional environment moderates the importance of managerial discretion. Specifically, we explore whether IQ moderates the value relevance of AIA after the 2008 IFRS 3 amendment. Importantly, we find that the value relevance of AIA post-2008 IFRS 3 amendment, is stronger in countryyears with high underlying IQ. This contributes to the existing literature by highlighting the role of the external institutional environment on the value relevance of accounting information. Overall, our results are robust to the choice of model, the estimation of acquired intangibles, self-selection bias and several endogeneity issues.

The rest of the paper is organised as follows. Section 2 discusses related literature and develops the hypotheses of interest, section 3 presents the data and methodology, and section 4 discusses our findings, whilst section 5 concludes the study.

\section{Literature review and hypotheses development}

\subsection{Accounting for acquired intangible assets}

In Africa, the accounting treatment for AIA mainly followed the recommendations of the International Accounting Standards (IAS 22 - Accounting for Business Combinations) even prior to the adoption of IFRS by African countries (Eloff \& de Villiers, 2015; Powell, 
2003). IAS 22 was superseded by IFRS 3 - Business Combinations in March 2004 and became effective for business combinations with agreement date after 30th March 2004 (IASB, 2008b). The release of IFRS 3 in 2004 coincided with a revision of IAS 36 Impairment of Assets and IAS 38 - Intangible Assets (IASB, 2008b). IFRS 3 made four far-reaching changes to the accounting for AIA. Firstly, IFRS 3 completely abolished the pooling of interest method and recommended that all AIA within the remit of IFRS 3 , be accounted for using the purchase method. Secondly, IFRS 3 required that AIA in a business combination be reported separately from goodwill. Thirdly, IFRS 3 required all AIA to be reported at fair value rather than at cost. Finally, IFRS 3 prohibited the amortization of AIA in favor of annual impairment testing subject to IAS 36 (IASB, 2008b). These changes were expected to increase the informativeness, reliability and comparability of AIA under IFRS 3.

Another version of IFRS 3 - Business Combinations was issued in January 2008 with an implementation date of July 2009 (IASB, 2008a). This revised version of IFRS 3 made an important change to the accounting for, and recognition of, AIA. Specifically, the 2008 version offers acquiring managers the discretion to recognize identifiable intangible assets not previously recognized by the acquired firm (Deloitte, 2008). Although this change has no effect on the accounting treatment of AIA, it may result in more AIA being recognized in business combination transactions (PWC, 2008). This is because it offers managers greater discretion in deciding which intangible assets to recognize in a business combination transaction (PWC, 2008). In this paper, our focus is on this additional discretion that the 2008 IFRS 3 amendment provides and whether this discretion translates into more informative financial reports.

\subsection{The value relevance of acquired intangible assets}

One financial reporting choice that less is known about is value relevance with respect to the discretion exercised by managers regarding the accounting treatment of intangible assets. Therefore, the central focus of this study is corporate intangibles, especially 
AIA. Admittedly, a limited number of studies have investigated the value relevance and decision usefulness of some form of intangible assets to users of accounting information. However, these studies also mainly focus on the developed markets, as well as general intangible assets rather than AIA. For example, using Australian data, Barth \& Clinch (1998) report a positive relationship between revalued intangible assets and both market and non-market-based value estimates. Similarly, Goodwin \& Ahmed (2006) find that Australian firms that capitalize intangible assets have increased value relevance. These results are discernibly consistent with those of other past studies (Abrahams \& Sidhu, 1998; Godfrey \& Koh, 2001; Shahwan, 2004) that documented a positive relationship between intangible assets and market-based value estimates.

In contrast, Godfrey \& Koh (2001) document that although goodwill and identifiable intangibles are value relevant, capitalized research and development are not. Also, Su \& Wells (2015) found that identifiable intangible assets acquired and recognized during business combinations for a sample of Australian acquirers were not related to postacquisition firm performance. Further, the findings of several others (Amir \& Lev, 1996; Beattie, 2005; Collins et al., 1997; Joos \& Lang, 1994) have questioned the value relevance of different items of intangible assets. Dahmash et al. (2009) attribute the conflicting results to the uniqueness of specific types of intangible assets such that their value relevance differs significantly from each other.

Thus, given these foregoing empirical findings on the value relevance of intangible assets in general, and the uniqueness of AIA, which results from the business combination process and the expectation by investors to benefit from the net assets of the acquired firm post-acquisition, we postulate that irrespective of managerial discretion, AIA should be value relevant to investors. Hence, our first hypothesis is:

$H_{1}$ : Recognized acquired intangible assets are value relevant. 


\subsection{The value relevance of acquired intangible assets after the 2008 IFRS 3 amendment}

Other studies have also investigated how intra-jurisdictional changes in accounting standards may affect the value relevance of intangible assets. Within this stream of literature, Oliveira et al. (2010) argue that changes in accounting standards may account for differences in the value relevance of intangible assets, especially when it is accompanied by increased managerial discretion. Consistent with this assumption, they investigated the value relevance of intangibles in Portugal pre- and post-IFRS adoption. They document that the change from Portuguese GAAP to IFRS had no impact on the value relevance of intangible assets. Further, their results suggested that the rule contained in IFRS 3 that allowed companies to subject intangible assets to impairment tests rather than amortization has improved the value relevance of intangible assets. Their result is consistent with Eloff \& de Villiers (2015), who indicated that goodwill reported according to IFRS 3 is more value relevant than goodwill reported under IAS 22. Similarly, using Swedish data, Hamberg \& Beisland (2014) find that goodwill balances are value relevant under both the Swedish GAAP and IFRS. However, goodwill impairment is value decreasing under Swedish GAAP, but insignificant under IFRS. These studies indicate that intrajurisdictional changes in accounting standards have value relevance effects on intangible assets.

Wyatt (2005) attributed the performance effects of intra-jurisdictional changes in accounting standards to changes in managerial discretion. The author argued that when accounting standards give management greater reporting discretion, intangible assets are more value relevant and valued by investors ${ }^{7}$. This is because discretion offers managers credible channels to circumvent legal and institutional barriers associated with the disclosure of certain private information to shareholders (Demski et al., 1984; Schipper,

\footnotetext{
${ }^{7}$ One reason for the increased informativeness of the amended post-2008 IFRS 3 over its 2004 version is that discerning investors can appreciate that managers have the opportunity to value all intangibles, including those that might have been previously unrecognized. This, therefore, enhances the possibility of valuing intangibles at their fair values, and hence, the investments of acquirers.
} 
1989; Tan \& Jamal, 2006). As a result, Dahmash et al. (2009) suggested that accounting standards with less limiting choice regarding the recognition of intangible assets have greater value relevance effects. Empirically, AbuGhazaleh et al. (2011) reported that managers capitalize on the increased managerial discretion offered by IFRS 3 to convey private information about the firm to investors. Similarly, Chambers et al. (2003) found that managerial discretion over R\&D costs recognition increases the value relevance of R\&D expenditures. These studies suggest that accounting standards that offer greater discretion to preparers increase the value relevance of intangible assets.

We note that the current version of IFRS 3 amended in 2008, made a significant change to the accounting and recognition of AIA in paragraph 13. This change offers the managers of the acquiring firms' greater discretion in the recognition of identifiable intangible assets (e.g., brand names, patents or customer relationships) that the target firms' managers had not previously recognized in their financial statements. The target firms' managers will not have previously recognized these assets in their financial statements because they were developed internally and the associated development costs charged to expense (Deloitte, 2008; IASB, 2008a). This significant change effected in the 2008 version of IFRS 3 provides an expectation that the intangible assets recognized post-acquisition based on the 2008 version of IFRS 3 would be significantly different from the intangible assets recognized by firms that are non-acquirers or firms that engaged in business combinations prior to the implementation of the 2008 version of IFRS 3. Thus, we contend that the greater managerial discretion in the post-2008 IFRS 3 amendment should result in more AIA being recognized in business combination transactions (PWC, 2008), and arguably should provide more value relevant information about AIA to investors. Thus, our second hypothesis is:

$\mathrm{H}_{2}$ : The information content of AIA is more value relevant after the 2008 IFRS 3 amendment. 


\subsection{Institutional quality, IFRS 3 amendment and value relevance}

In Africa and other developing countries with institutional settings that feature relatively weak regulatory environments, poor enforcement mechanisms, illiquid capital markets, and inefficient stock markets (Bertrand et al., 2002; Ntim et al., 2012; Samaha et al., 2012; Tunyi \& Ntim, 2016), there is an argument that IFRS, as a whole, may not enhance the value relevance of accounting information of African firms (Bova \& Pereira, 2012) due to the higher level of discretion. Specifically, with regards to IFRS 3, the greater managerial discretion provided by the 2008 IFRS amendment may render reported AIA less value relevant due to the potential for managers to exercise this discretion for opportunistic purposes. Thus, we investigate whether the IQ in the African countries studied has an impact on the value relevance of AIA post the 2008 IFRS 3 amendment. We expect to observe that managerial discretion improves the value relevance of AIA only when underlined by strong institutions. Hence, our third hypothesis is:

$H_{3}$ : Institutional quality positively moderates the value relevance of AIA in Africa post 2008 IFRS 3 amendment.

\section{Data and model development}

\subsection{Sample selection and data}

Our analysis is conducted using a sample of African acquirers. We first generate the list of all listed firms (live and dead) between $2004^{8}$ and 2016 across all African stock exchanges. We obtain a list of 2,516 unique firms. We then collect a panel of financial and accounting data for these firms (covering the 2004 to 2016 period) from Thomson DataStream. ${ }^{9}$ Next, we collect our business combination or M\&A deal data from Thomson One. We focus on M\&A transactions, which fall within the remit of business combinations as per

\footnotetext{
${ }^{8}$ IFRS 3 was effective from 31 March 2004 .

${ }^{9}$ To enhance comparability and avoid currency effects and distortions, we collect our cross-country data in a single currency - US dollars.
} 
IFRS 3 (i.e., transactions in which an acquirer obtains control or over $50 \%$ voting rights of one or more businesses). Our dataset covers all M\&As completed by African firms (acquirers) for African and international targets over the period 2004 to 2016. We match our business combination data to firm-level variables based on DataStream codes and years. Finally, we obtain information about each country's year of IFRS adoption from IFRS Foundation web page (IFRS-Foundation, 2019). We generate a clean sample for use in our main analysis by making three exclusions;

1. We exclude all firm-year observations with no business combination activity. ${ }^{10}$

2. We exclude all firms in countries that had not adopted IFRS by the end of $2016 .{ }^{11}$

3. For each country, we exclude all firm-year observations prior to the year in which the country adopts IFRS. ${ }^{12}$

These exclusions make our research design appropriate for isolating the effect of the 2008 IFRS 3 amendment. After making the exclusions, we are left with a sample of 603 relevant business combinations across 7 African countries. Table 1 summarises the distribution of M\&A deals across each country and presents information on IFRS adoption years across each country.

[Insert Table 1 here]

\subsection{AIA, IFRS 3 amendment and institutional quality}

Documenting the value of reported AIA across firms involved in business combinations remains a challenge in this line of research. As part of Purchase Price Allocation (PPA),

\footnotetext{
${ }^{10}$ In our robustness tests, we use the full sample of all listed firms (acquirers and non-acquirers) in M\&A active countries to address selection bias issues.

${ }^{11}$ For example, countries such as Tunisia and Ivory Coast (which did not adopt IFRS regulations before 2016) and Egypt (which allows only foreign companies with dual listing in Egypt to use IFRS standards) are excluded.

${ }^{12}$ For example, Nigeria only adopted IFRS in 2010, so we exclude all firm-year observations for companies in Nigeria prior to 2010.
} 
IFRS 3 requires firms to allocate the cost of a business combination by recognizing acquired assets at fair value (i.e., identify, value and separately include different AIAs in the balance sheet). The list of intangibles that can potentially be recognized is extensive $^{13}$ and disclosure practice varies across firms. Details of intangibles acquired might be reported in notes to financial statements, but because they are not regularly mandatorily reported in a specified format, this data is not collated by standard databases, such as Thomson DataStream, which we use in this study. Some institutions, such as Houlihan Lokey routinely collect data on the details of PPA (under US GAAP), but this data is only available for US firms.

One way to address the issue ${ }^{14}$ is to use hand-collected data. This is laborious, expensive, impractical in some instances, and may limit the scope of the research. Besides the issue of cost, several firms (particularly, in Africa) do not routinely disclose AIA information as a standalone item in their financial statements. An alternative solution to the problem of AIA data unavailability is to use a suitable proxy. Su \& Wells (2015), for example, use acquisition premiums, as a proxy for AIA. This measure is, at best, a noisy proxy, as it is unclear to what extent premiums account for AIA in the target firm, particularly the unrecognized intangibles that the acquirer now has the discretion to recognize based on the 2008 IFRS 3 amendment. Premiums might also represent the acquirer's perception of value to be created through more efficient deployment of the target's assets (Tunyi et al., 2019). Event study methodologies could also be used to more precisely isolate the value relevance of AIA at the time of the deal. Given our African context, and the inherent illiquidity and stock market efficiency problems, this technique might prove sub-optimal. Hence, given the need to rely on end of the year (annual)

\footnotetext{
${ }^{13}$ This may include, amongst others, marketing-related (e.g., internet domain names, non-compete agreements, brands, trademarks), customer-related (e.g., contracts, customer lists, and customer relationships), artistic-related (books, musical works, videos, and photographs), contract-based (e.g., royalty agreements, licensing, construction permits, broadcasting rights, servicing contracts, employment contracts, lease agreements, contracts for advertising, construction, management and supply) and technology-based (e.g., software, databases, trade secrets, patented and unpatented technology) intangibles.

${ }^{14}$ That is, the unavailability of data on intangibles acquired during business combination in standard databases.
} 
figures, we propose a strategy for estimating AIA from routinely reported annual data.

In this study, we estimate AIA as the difference in the acquirer's total intangible assets pre- and post-acquisition. in essence, AIA captures the difference between the most recent value of a firm's total intangible assets published before a deal is announced and the value of total intangible assets immediately after the deal is completed. The rationale is that a significant increase in the acquirer's intangibles after an acquisition arises primarily due to intangibles acquired through the acquisition process. We recognize that total intangibles can grow naturally through firms' investments, hence, as an extension (in robustness analysis), we adjust our measure of AIA by subtracting an estimate of each firm's annual (natural or expected) growth in intangibles. Our AIA measure has several benefits over traditional proxies (e.g., acquisition premiums) and hand-collected data. Specifically, it is easy to compute and it relies on readily available and easily obtainable financial data (total intangible assets). Additionally, given that it does not involve hand collection, it allows us to explore a relatively large sample of M\&A cases.

For each acquiring firm $i$ at time $t$, as in equation 1, we estimate AIA as the difference in total intangibles (net) pre $\left(I N T_{t-1}\right)$ and post deal completion $\left(I N T_{t}\right)$, whereby the deal occurs in a period that lies between $t-1$ and $t$. We deflate this variable by the opening period number of shares. The pattern or likelihood of intangible impairments may have changed after the amendment. To remove the impact of such a change, for robustness, as shown in equation 1a, we add back total impairments of intangibles in year $t$ to our measure of intangibles in equation $1 .^{15}$

$$
\begin{gathered}
A I A_{i t}=I N T_{t}-I N T_{t-1} \\
A I A_{i t}=I N T_{t}-I N T_{t-1}+\text { Impairments }_{t}(\text { goodwill and other intangibles })
\end{gathered}
$$

A number of studies have explored the value relevance of goodwill arising from business combinations (Eloff \& de Villiers, 2015; Godfrey \& Koh, 2001; Hamberg \& Beisland,

\footnotetext{
${ }^{15}$ Our results are robust to this addition.
} 
2014; Higson, 1998). Hence, consistent with the literature, we dissociate our measure of AIA into two components; acquired goodwill $(A G W)$ and other (non-goodwill) acquired intangible assets $(O A I A)$. Given that goodwill can only be acquired (but not generated internally), we estimate $A G W$ as the difference in reported goodwill (net of impairments) before a deal is announced and reported goodwill (net of impairments) after a deal is completed (equation 2). Clearly, any significant change in goodwill after an acquisition is likely to be the result of acquired goodwill. For robustness, as shown in equation 2a, we also remove the impact of a possible change in the pattern of goodwill impairments after the amendment by adding back goodwill impairment in year $t$ to our measure of Goodwill in equation 2. ${ }^{16}$ As shown in equation 3, OAIA is, therefore, the difference between AIA and AGW in the year of acquisition. This variable is deflated by opening period number of shares.

$$
\begin{gathered}
A G W_{i t}=\text { Goodwill }_{t}-\text { Goodwill }_{t-1} \\
A G W_{i t}=\text { Goodwill }_{t}-\text { Goodwill }_{t-1}+\text { Impairments of goodwill }_{t} \\
O A I A_{i t}=A I A_{t}-A G W_{t}
\end{gathered}
$$

As earlier noted, our measure of AIA implicitly assumes that any change in total intangibles when a deal is completed can be attributed to intangibles acquired during the acquisition process. It is indeed the case that some firms routinely grow their levels of intangibles from one year to another by, for example, investing in R\&D, amongst others. Therefore, our measure might systematically overestimate AIA. To adjust for the natural growth in intangibles, in our robustness analysis, we assume a normal increase in intangibles each year, which we approximate as the average yearly change in intangibles $(\triangle I N T)$ over the last two years. As shown in equation 4, we therefore, adjust our estimate of acquired intangibles by subtracting the average increase in intangibles over the last two years. We refer to this adjusted measure as AIA2. As an extension, we also

\footnotetext{
${ }^{16}$ Our results are robust to this alternative specification.
} 
adjust our AIA measure by subtracting the average yearly change in total intangibles in all prior years until 2004, from AIA. We refer to this adjusted measure as AIA3. Importantly, some firms in our sample have been previously involved in M\&A deals. These previous deals might have resulted in a significant increase in total intangibles. To isolate this in our analyses, we disregard all previous years with acquisitions when estimating the natural growth in intangibles. In additional tests, we use adjusted measures of AIA (i.e., AIA2 and AIA3) to retest our hypotheses. ${ }^{17}$

$$
A I A 2_{i t}=I N T_{t}-I N T_{t-1}-\frac{1}{2}\left(\Delta I N T_{t-1}+\Delta I N T_{t-2}\right)
$$

Different African countries adopted IFRS standards in different years (see Table 1) and our data set excludes firm-year observations that do not use IFRS. The IFRS 3 (2008) amendment has an implementation date of July 2009 (IASB, 2008a) and is applicable to all Business Combinations from the 2009 financial year. We use an indicator variable (IFRS3A) to capture the impact of the amendment. IFRS3A takes a value of 1 when financial year is greater than 2009 and a value of 0 when the financial year is less than 2009. ${ }^{18}$

Our measure of IQ is derived from Kaufmann et al. (2010) World Governance Indicators (WGIs). Kaufmann et al. (2010) use data from various sources to generate indices, which measure; Control of Corruption (CCI), Government Effectiveness (GEI), Voice and Accountability (VAI), Regulatory Quality (RQI), Political Stability and Absence of Violence (PSAVI) and Rule of Law (ROLI). Kaufmann et al. (2010) link the six measures to three important governance areas, including: (i) the process by which governments are selected, monitored and replaced (VAI, PSAVI); (ii) the capacity of the government to

\footnotetext{
${ }^{17}$ In general, we find that our conclusions remain unchanged when we use the more complex or adjusted measures. We also find that there is no statistically significant difference between AIA, AIA2 and AIA3. Hence, for simplicity, we use the simple measure (AIA) dissociated into AGW and OAIA, in our main analyses and report results for the adjusted measures (AIA2 and AIA3) as part of the battery of robustness checks we have conducted.

${ }^{18}$ We exclude 2009 given that this was a transition year. In robustness tests, we have used alternative definitions which include 2009, and our results are qualitatively similar.
} 
effectively formulate and implement sound policies (GEI, RQI); and (iii) the respect of citizens and the state for the institutions that govern economic and social interactions among them (ROLI, CCI). We use principal component analysis to reduce these 6 WGIs into a single component, which is used as our measure of IQ. We discuss this in more detail in section 4.4 .

Table 2 presents variable definitions for the main variables in our study. These variables include measures of firm value, acquired intangibles, IQ and the set of control variables included in our models. We discuss our empirical models in section 4.

[Insert Table 2 here]

\section{Results and discussions}

\subsection{Descriptive statistics}

In panel A of Table 3, we present descriptive statistics for measures of AIA, AGW and OAIA (in dollars per share). ${ }^{19}$ The 25 th percentile values for AIA estimates are negative in some countries, including Kenya and South Africa. In Panel B of Table 3, we present further details of the distribution of all variables used in the study for the sample of African acquirers. Given that the 2008 IFRS 3 amendment gives managers more discretion in deciding which intangible assets to recognize following business combinations, we might expect to observe a significant jump in AIA after the amendment. Our preliminary results suggest otherwise. Consistent with the results from Figure 1, acquirers appear to rather report higher values of AIA in the pre-amendment or pre-2009 period compared to the post-amendment or post-2009 period. Specifically, we find that the mean values of AIA, AGW and OAIA are higher pre-2009. Also, the distribution of AIA between AGW and OAIA appears to have changed substantially after 2009. Specifically, the median value of AGW decreased from 0.026 to 0.000 while the median value of OAIA increased

\footnotetext{
${ }^{19}$ To mitigate the effects of possible outliers, our variables are winsorized at the 1st and 99th percentile of the country-year distribution.
} 
from 0.000 to 0.001 . Notice that, as shown in Table 3, AGW makes up a significantly larger portion of AIA when compared to OAIA. The mean value of AGW is 0.234 , while the mean value of OAIA is only 0.149 .

[Insert Figure 1 here]

[Insert Table 3 here]

\subsection{Value relevance of AIA}

Our first hypothesis $\left(H_{1}\right)$ predicts that recognized AIA (as per IFRS 3) are value relevant. Hence, we explore the relationship between acquired intangibles and firm value. We use two main empirical models to test this hypothesis. As in equation 5, our first model explores the association between measures of AIA (i.e., AGW and OAIA) and Tobin's Q (as a proxy of firm value $)^{20}$ after controlling for firm and industry characteristics, as well as, prevailing external market conditions. Similar models have been used to test value relevance in the accounting literature (see Hasso \& Duncan, 2013, for a review).

$$
V A L U E_{i t}=\beta_{0}+\beta_{1} A G W_{i t}+\beta_{2} O A I A_{i t}+\beta_{n} C O N T R O L_{i t}+v_{t}+v_{j}+\epsilon_{i t}
$$

In equation 5, we control (CONTROL) for firm liquidity, leverage, free cash flow, tangible assets, firm size and firm age, as well as, industry $(j)$ and year $(t)$ fixed-effects. If AIA is value relevant, we should observe a positive and significant coefficient for AGW and/or OAIA when we estimate the model. Our second approach to test for value relevance of AIA employs a standard Price model, which has consistently been used in the extant accounting literature (Alali \& Foote, 2012; d'Arcy \& Tarca, 2018; Han \& Manry, 2004; Ohlson, 1995).

$$
P_{i t}=\beta_{0}+\beta_{1} A G W_{i t}+\beta_{2} O A I A_{i t}+\beta_{3} E P S_{i t}+\beta_{4} B V P S_{i t}+v_{t}+v_{j}+\epsilon_{i t}
$$

\footnotetext{
${ }^{20}$ For robustness, we have also used market to book to proxy for firm value. Our results and conclusions are similar. Hence, for conciseness we only present results for one measure (Tobin's Q) throughout the study.
} 
Here, as in equation 6, we modify the standard Price model by including measures of acquired intangibles (AGW and OAIA) in the model. ${ }^{21}$ The model explores the relationship between recognized AIA and price per share given firm-level earnings (EPS) and book value (BVPS) per share. As in equation 5, if AIA is value relevant, we should observe a positive and significant coefficient for AGW and/or OAIA when we estimate the model. Equation 6 also controls for industry $(j)$ and year $(t)$ fixed-effects. The inclusion of industry fixed-effects (in these and subsequent models) removes any industry-specific value relevance, while the inclusion of year fixed-effects controls for changing economic and institutional conditions through time. The industry and year fixed-effects partly address omitted variable bias in our models.

Our regression estimates for equations 5 and 6 are presented in Table 4. In Column 1, we conduct the analysis for our full data set (including all African acquirers between 2004 and 2016) as specified by equation 5. We find that AGW and OAIA are not significantly associated with Tobin's Q over the full period, suggesting that firm value does not increase with AIA. Specifically, a unit increase in AGW (or OAIA) is associated with a $0.3 \%$ (or $2.0 \%$ ) increase in firm value (as measured by Tobin's Q). In both cases, the coefficients are not statistically significant at the $10 \%$ level. In Column 4, we use the Price model (specified in equation 6) to again explore whether AIA is value relevant for our sample of firms between 2004 and 2016. Here, we find that AGW is positively associated with Price (i.e., coefficient of 0.563 and $p$-value of 0.846 ), while OAIA and Price have a negative relationship (i.e., coefficient of -1.088 and $p$-value of 0.781). Again, the coefficients are not statistically significant at the $10 \%$ level. The results from Columns 1 and 4 summarily suggest that, over the full period (2004-2016), firm value does not generally increase with AIA. In untabulated results, we find that AIA (the sum of AGW and OAIA) does not have a significant positive relationship with Tobin's Q or Price. Overall, our results do not support our first hypothesis of a positive relation between AIA and firm value.

This finding is inconsistent with prior studies on the value relevance of intangible

\footnotetext{
${ }^{21}$ Notice that the correlation coefficient between AGW and OAIA (untabulated) is 0.04, suggesting that there are, perhaps, no concerns about potential multicollinearity.
} 
assets. Indeed, Barth \& Clinch (1998), Godfrey \& Koh (2001) and Goodwin \& Ahmed (2006) suggest that the total reported intangible assets are value relevant to investors. Similar to Su \& Wells (2015), we explore intangibles acquired during business combinations (AIA), and our results are consistent with Su \& Wells (2015), who find no significant relationship between AIA and post-acquisition firm performance. The Su \& Wells (2015) study covers the period 1988-2008 and, hence, does not cover the period after the 2008 IFRS 3 amendment. We have argued that the 2008 IFRS 3 amendment gives managers more discretion in recognizing AIA, and hence may improve the value relevance of reported AIA. In the next part of our study, we, thus, explore the impact of the 2008 IFRS 3 amendment as discussed in our second hypothesis $\left(H_{2}\right)$.

\subsection{Value relevance of AIA and the IFRS 3 amendment}

Our second hypothesis $\left(H_{2}\right)$ argues that the information content of AIA is more value relevant after the 2008 IFRS 3 amendment, especially given the discretion it gives acquiring managers to recognize previously unrecognized intangible assets in the acquired firm. To test the extent to which the amendment increased the value relevance of recognized AIA, we use standard interaction effects. Specifically, we expand equations 5 and 6 by interacting IFRS3A with measures of AGW and OAIA. This gives rise to equations 7 and 8 below. As in previous equations (5 and 6), we control for firm characteristics, as well as, industry $(j)$ and year $(t)$ fixed-effects.

$$
\begin{gathered}
V A L U E_{i t}=\beta_{0}+\beta_{1} A G W_{i t} * I F R S 3 A_{t}+\beta_{2} O A I A_{i t} * I F R S 3 A_{t}+ \\
\beta_{3} A G W_{i t}+\beta_{4} O A I A_{i t}+\beta_{5} I F R S 3 A_{t}+\beta_{n} C O N T R O L_{i t}+v_{t}+v_{j}+\epsilon_{i t} \\
P_{i t}=\beta_{0}+\beta_{1} A G W_{i t} * I F R S 3 A_{t}+\beta_{2} O A I A_{i t} * I F R S 3 A_{t}+ \\
\beta_{3} A G W_{i t}+\beta_{4} O A I A_{i t}+\beta_{5} I F R S 3 A_{t}+\beta_{6} E P S_{i t}+\beta_{7} B V P S_{i t}+v_{t}+v_{j}+\epsilon_{i t}
\end{gathered}
$$


The results we obtain from estimating these equations are presented in Columns 2, 3, 5 and 6 of Table 4. In Column 2, we find that IFRS3A has a positive interaction effect on the AGW-Tobin's Q, as well as, the OAIA-Tobin's Q relationships. In both cases, the interaction effect is statistically significant at the $10 \%$ level. In Column 3, we test whether these results are robust to adjustment for a possible change in the pattern of impairments after the amendment i.e., when AGW and OAIA are adjusted for impairments as in equation 2a. Again, we find that the results are robust to this adjustment as the interaction effects are significant at the $10 \%$ level. In Column 5, we explore the aforementioned interaction effects using the Price model. Here, we similarly find a positive and significant interaction effect (at the 10\% level) between IFRS3A and AGW, as well as, between IFRS3A and OAIA. As in Column 6, these results are robust to alternative specifications of AGW and OAIA i.e., whether or not we account for potential changes in impairments after the amendment. These results suggest that IFRS3A increases or amplifies the value relevance of AGW and OAIA. These results are not driven by potential changes in the pattern of impairments after the 2008 IFRS 3 amendment. ${ }^{22}$

[Insert Table 4 here]

Overall, our results from Table 4 summarily suggest that AIA have become more relevant to investors since the 2008 IFRS 3 amendment, as evidenced by a strong positive relation between AIA and Tobin's Q post the 2008 IFRS 3 amendment - a relationship, which did not exist in the pre-amendment period. ${ }^{23}$ Put together, these results suggest that AIA had a limited impact on firm value in the pre-amendment period as suggested by Su \& Wells (2015), but potentially increased firm value in the post-amendment period. These results support our second hypothesis $\left(H_{2}\right)$ and provide evidence of the value

\footnotetext{
${ }^{22}$ For robustness, we also exclude Namibia from our sample (given its negative mean and median OAIA value as shown in Table 3) and rerun the analysis. We find that the results remain qualitatively similar.

${ }^{23}$ We establish this using an asymmetric variant of equations 5 and 6 , which allows the slope coefficient of acquired intangibles in Columns (1) and (3) to be different for the pre- and post-2008 IFRS 3 amendment periods (e.g., Aktas et al., 2015). These additional results are untabulated due to space restrictions, but are available upon request. Our results from the analyses suggest that AIA (i.e., AGW and OAIA) was not value relevant in the pre-amendment period, but became value relevant in the post-amendment period.
} 
relevance of the 2008 IFRS 3 amendment. In particular, the results suggest that the discretion provided to managers of the acquiring firms to recognize the previously unrecognized intangible assets in acquired firms under the 2008 IFRS 3 amendment provides value relevant information regarding intangible assets acquired during business combinations. These results are robust to several empirical choices (e.g., alternative measures and endogeneities).

\subsection{Does Institutional quality matter?}

Our third hypothesis $\left(H_{3}\right)$ contends that IQ positively moderates the value relevance of AIA in Africa post-2008 IFRS 3 amendment. That is, post 2008 IFRS 3 amendment, AIA is likely to be more value relevant in environments with comparatively higher IQ.

Our measure of IQ is derived from Kaufmann et al. (2010) World Governance Indicators (WGIs), which we discuss in section 3.2. ${ }^{24}$ As shown in Panel A of Table 5, notice that these 6 measures, while capturing different dimensions of IQ, are highly correlated. Hence, we cannot include them together in our regression as this will lead to multicollinearity problems. Consistent with Elamer et al. (2017) and Konara \& Shirodkar (2018), we use Principal Component Analysis (PCA) to reduce these six WGIs (CCI, GEI, VAI, PSVAI, RQI and ROLI) into factors, which we use in our multivariate analysis. Our PCA results are presented in Panel B of Table 5. These results suggest that the first principal component captures a significant proportion of the variance $(89.6 \%)$ explained by each component. The second to sixth components only capture $4.9 \%, 2.6 \%$, $1.7 \%, 0.9 \%$ and $0.4 \%$ of the variance, respectively. Further, we find that the eigenvalue of the first component is 5.377 , while the eigenvalues for all the other components are below 1. We, therefore, use only the first principal component as our composite measure of IQ. Notice that instead of using PCA to generate WGIC, we could simply average the 6 WGIs for each country in each year to derive a composite measure since the measures

\footnotetext{
${ }^{24}$ Kaufmann et al. (2010) derive yearly indices, which measure; Control of Corruption (CCI), Government Effectiveness (GEI), Voice and Accountability (VAI), Regulatory Quality (RQI), Political Stability and Absence of Violence (PSAVI) and Rule of Law (ROLI), across countries.
} 
have the same scale and range (Kaufmann et al., 2010). Indeed, we do so as a robustness check and find that our conclusions remain robust. ${ }^{25}$ In Panel $\mathrm{C}$ of Table 5, we present average measures of WGIs across countries.

\section{[Insert Table 5 here]}

Our hypothesis $\left(\mathrm{H}_{3}\right)$ explores the extent to which the value relevance of the acquired intangibles pre- and post-the 2008 IFRS 3 amendment depends on the broader underlying IQ. Specifically, we want to investigate whether the value relevance of AIA post-IFRS 3 amendment is higher in countries with comparatively better institutional environments. In Table 6, we explore the moderating effect of IQ on the value relevance of AIA (i.e., AGW and OAIA) after the IFRS 3 amendment by first (Panel A) testing a three-way interaction effect among AIA, IFRS3A and IQ as specified in equations 9 and 10.

$$
\begin{gathered}
V A L U E_{i t}=\beta_{0}+\beta_{1} A G W_{i t} * I F R S 3 A_{t} * I Q_{t}+\beta_{2} O A I A_{i t} * I F R S 3 A_{t} * I Q_{t}+ \\
\beta_{3} A G W_{i t} * I F R S 3 A_{t}+\beta_{4} O A I A_{i t} * I F R S 3 A_{t}+\beta_{5} A G W_{i t} * I Q_{t}+ \\
\beta_{6} O A I A_{i t} * I Q_{t}+\beta_{7} I F R S 3 A_{t} * I Q_{t}+\beta_{8} A G W_{i t}+\beta_{9} O A I A_{i t}+ \\
\beta_{10} I F R S 3 A_{t}+\beta_{n} C O N T R O L_{i t}+v_{t}+v_{j}+\epsilon_{i t}
\end{gathered}
$$

$$
\begin{array}{r}
P_{i t}=\beta_{0}+\beta_{1} A G W_{i t} * I F R S 3 A_{t} * I Q_{t}+\beta_{2} O A I A_{i t} * I F R S 3 A_{t} * I Q_{t}+ \\
\beta_{3} A G W_{i t} * I F R S 3 A_{t}+\beta_{4} O A I A_{i t} * I F R S 3 A_{t}+\beta_{5} A G W_{i t} * I Q_{t}+ \\
\beta_{6} O A I A_{i t} * I Q_{t}+\beta_{7} I F R S 3 A_{t} * I Q_{t}+\beta_{8} A G W_{i t}+\beta_{9} O A I A_{i t}+ \\
\beta_{10} I F R S 3 A_{t}+\beta_{11} E P S_{i t}+\beta_{12} B V P S_{i t}+v_{t}+v_{j}+\epsilon_{i t}
\end{array}
$$

Consistent with our previous analyses, equations 9 and 10 control for firm characteristics, as well as, industry $(j)$ and year $(t)$ fixed-effects. Besides addressing omitted variable bias in our models, these fixed-effects summarily control for any industry-specific value

\footnotetext{
${ }^{25}$ The two measures of WGIC are highly correlated with a correlation coefficient of $99.9 \%$.
} 
relevance, as well as any world-wide macro effects. If IQ moderates our earlier results in Table 4 (i.e., the value relevance of AGW and OAIA increase post-amendment), we should observe a significant three-way interaction effect. Such a significant three-way interaction effect will suggest that the moderating effect of the IFRS 3 amendment (IFRS3A) on the acquired intangibles-firm value nexus varies across different levels of IQ. Our PCA measure of IQ is a continuous variable. Hence, in order to facilitate the interpretation of the three-way interaction effects, we generate a binary equivalent (High_IQ) and use in our analysis. As noted in Table 2, High_IQ takes a value of 1 if IQ is greater than the median IQ in that year. Our regression estimates and associated marginal effects are presented in Table 6 .

[Insert Table 6 here]

As shown in Columns 1 (Tobin's Q equation) and 3 (Price equation) of Table 6, we find a significant three-way interaction effect between IFRS3A, High_IQ and AGW. In Columns 3 and 4 (Price equations), we also find significant three-way interaction effects between IFRS3A, AGW and measures of IQ. To understand the nature of these interaction effects, we compute marginal effects which, in essence, explore the relationship between AIA and firm value at different levels of IFRS3A and High_IQ. The marginal effects in Columns 1 and 3 suggest that, as hypothesised $\left(H_{3}\right)$, AGW improves firm value post-IFRS (i.e., $\operatorname{IFRS3A}=1$ ) when IQ is high (i.e., High_IQ = 1). However, the results from the Price model (Columns 2 and 3) are inconclusive as we find that OAIA enhances firm value after the amendment when IQ is low and that AGW also enhances firm value before the amendment when IQ is low.

Perhaps, a more direct test of $H_{3}$ is to explore $H_{2}$ (i.e., Columns 2 and 5 of Table 4) across sub-samples of firms in low and high IQ environments. Specifically, we estimate equations 7 and 8 conditional on High_IQ being equal to zero (i.e., for firms in poor institutional environments) and, again, conditional on High_IQ being equal to 1 (i.e., for firms in good institutional IQ environments). We present our results for this sub-sample analyses in Table 7. Control variables in Columns 1, 3 and 5 are suppressed to save space. 
We find that the interaction effect which we documented in Column 2 of Table 4 disappears when we focus on a sub-sample of acquirers in low IQ environment (Column 1 of Table 7). In the Price model, we find that in low IQ environments (Column 2 of Table 7), the amendment reduced the value relevance of AGW, but increased the value relevance of OAIA. Notice that as shown in Table 2, AGW is about 1.6 times larger than OAIA i.e., OAIA makes up a relatively smaller proportion of AIA (when compared to AGW). In untabulated results, we therefore explore the relationship between AIA (the sum of AGW and OAIA) and firm value across our two sub-samples. These untabulated results confirm our findings in Column 1-the moderating effect of IFRS3A on the AIA-Tobin's Q relationship is not statistically significant (at the 10\% level) in low IQ environments. The untabulated results also shed light on the mixed finding in Column 2 of Table 7 by showing that, when taken together (i.e., the sum of AGW and OAIA), the moderating effect of IFRS3A on the AIA-Price relationship is also not statistically significant in low IQ environments. Overall, our results from Columns 1 and 2 of Table 7 suggest that the IFRS 3 amendment does not appear to enhance the value relevance of AGW and OAIA in poor institutional environments.

In contrast, in Columns 3 and 4 of Table 7, we find that the interaction effects (between IFRS3A and measures of AIA) are positive and significant in high IQ environments, under both Tobin's Q and Price models. This supports our third hypothesis $\left(H_{3}\right)$ that the underlying institutional environment moderates the value relevance of AIA after the amendment. As an additional test, we explore the extent to which the coefficients of the interaction terms are statistically different. ${ }^{26}$ The results suggest that coefficients of the interaction effect are generally greater when IQ is higher, particularly in the case of IF RS3A*AGW (significant at the $5 \%$ level).

Overall, our results suggest that the quality of the underlying institutional environ-

\footnotetext{
${ }^{26}$ Here, consistent with Cleary (1999), we use simulation tests and a bootstrapping procedure $(10,000$ bootstrapped samples) to calculate empirical p-values that estimate the likelihood of observing the differences in coefficient estimates when the coefficients are, in fact, equal.
} 
ment plays an important role in shaping investors' perceptions of the value of AIA reported by acquiring managers after the IFRS 3 amendment. Investors appear to attach more importance to managerial discretion when the underlying institutional environment is strong. These results are consistent with our third hypothesis. The results are also consistent with Gong et al. (2016), who find that the value relevance of intangibles, specifically, R\&D expenses under IFRS, is higher in European countries with stronger investor protection. In untabulated analysis, we explore whether our results vary across different WGI measures (CCI, GEI, VAI, PSVAI, RQI and ROLI). In essence, we run all our analyses using individual WGI as measures of IQ. We find that the results and conclusions are consistent (and do not change) across these variables. For brevity, we do not report these additional results.

\subsection{Robustness checks and additional analyses}

We have addressed a number of sources of endogeneity in our analysis, including omitted variables (through the use of year and industry fixed-effects) ${ }^{27}$, but we are left with the issue of self-selection bias. It is possible that specific firms self-select into the acquirer subsample which our study focuses on. For example, more established, larger and reputable firms, with good analyst following are more likely to engage in mergers \& acquisitions. Thus, it is possible that the impact we report (value relevance) for acquirers is due to the greater visibility (size, analyst following, reputation) that these firms enjoy rather than the level of AIA reported.

In additional tests, we use the Heckman Two-Stage method (Heckman, 1979) to correct for self-selection bias. This requires us to extend our dataset to cover all listed firms in African countries with Business Combination activity (i.e., a panel dataset). We create a new variable, Acquirer, which takes a value of 1 if a firm completes a takeover in a specific period and a value of 0 , otherwise. In the first stage of the Heckman Two-Stage

\footnotetext{
${ }^{27}$ In untabulated results, we have also addressed reverse-causality in our Tobin's Q model through the use of lagged independent variables. Our results are qualitatively similar. Hence, for brevity we do not present them here.
} 
model, we estimate the likelihood of making acquisitions conditional upon observed firm characteristics using a probit model. This allows us to compute the Inverse Mills Ratio (the non-selection hazard) following the Heckman (1979) approach. We then use the Inverse Mills Ratio as an additional control variable in the second stage (i.e., in all our regression models, we add the Inverse Mills Ratio as an additional control variable).

Additionally, we control for possible transition years given the fact that some firms might have retrospectively applied the IFRS 3 amendment. ${ }^{28}$ We consider the period from 2007 to 2010 as transition years. We create an indicator variable, Transition, which takes a value of 1 for years between 2007 and 2010 (inclusive) and a value of 0, otherwise. We use this variable as an additional control variable in our main analysis. In untabulated results, we find that the coefficient of the Inverse Mills Ratio is negative and statistically significant (at the 1\% level), suggesting that our results are prone to selection bias. We also find the coefficient of Transition to be negative and statistically significant at the $10 \%$ level in the two models. We find, however, that once we control for selection bias (or transition years) by including the Inverse Mills Ratio (or Transition) as an additional control variables, our main results and conclusions do not change qualitatively. Specifically, we generally find a positive and statistically significant interaction effect between IFRS3A and AGW, and between IFRS3A and OAIA after controlling for selection bias and transition years.

One question that remains is whether our analysis actually captures the impact of IFRS 3 and the 2008 IFRS 3 amendment. Note that IFRS 3 amendment, as an external shock to IFRS adopters, enters our analysis as a time period (i.e., all years post-2009). It is possible that this variable (IFRS3A) could also capture or proxy for some other external shocks, such as external regulations impacting on all African firms, the 2008 financial crisis or something else, which we are unaware of. To address this source of potential endogeneity, we compare results for African countries that have adopted IFRS standards

\footnotetext{
${ }^{28}$ In the 2008 amendments to IFRS 3 , the IASB permitted, but did not require firms to apply the amendments to transactions that occurred before the effective date of the amendment, which was 1 July, 2009 (IASB, 2008).
} 
(adopters) against those that have not adopted these standards (non-adopters). If our previous results are robust, then, we expect that the results (i.e., a significant change in value relevance of intangibles post-2009) should only hold in our sample of adopters. A number of countries in our sample, including Egypt and Tunisia, have not formally adopted IFRS standards. Hence, we use acquirers in non-IFRS adopters (Egypt and Tunisia), as a control to explore whether our results capture the impact of IFRS 3 rather than some other exogenous shock, which we have not accounted for. Contrary to our results in Table 4, here, we do not find a significant interaction effect. We also retest this using the Price model. We find a negative and statistically significant ( $p$-value of 0.001) interaction effect between IFRS3A and AGW for firms in non-adopting countries, suggesting a decline in the value relevance of AGW post-2009 (which coincides with the IFRS 3 amendment). The results for the interaction effect between OAIA and IFRS3A are not statistically significant. Given that our results for non-adopters do not mirror the conclusions of our results from the previous analyses, it is unlikely that our IFRS3A measure captures different external shocks (other than the 2008 IFRS 3 amendment) affecting all African acquirers.

In our final robustness check, we explore alternative definitions of AIA (i.e., AIA, AIA2 and AIA3). In our previous analyses, we dissociated AIA into two key components; AGW and OAIA, and showed that our results hold when we do so. The results (not tabulated) show that our findings hold and our conclusions do not change when we use the aggregated measure. That is, the 2008 IFRS 3 amendment improved the value relevance of intangible assets acquired during business combinations and this effect is stronger in countries with strong institutional environments.

Note that our measure of AIA simply considered the difference (change) in total intangibles pre- and post- completion of an acquisition as the value of intangible assets acquired during the acquisition. We noted that it was possible that some of the change in intangibles can be attributed to a firm's routine investment in intangibles (such as through its $\mathrm{R} \& \mathrm{D}$ activities). To account for this possibility of routine investment in intangibles, 
we subtracted an estimate of normal (or expected) investment in intangibles from our measure of AIA. In the first instance, we obtain the normal investment in intangibles as the average investment in intangibles over the previous two periods (AIA2). In the second instance, we compute the normal investment in intangibles as the average investment in intangibles in the previous period up until 2004 when IFRS 3 was effective (AIA3). In both cases, we exclude years in which a firm was previously involved in acquisitions from our analysis (so as not to inflate the expected value).

In untabulated analysis, we find that the 3 measures of acquired intangibles (AIA, AIA2 and AIA3) are correlated. AIA2 and AIA3 are, particularly, highly correlated with a correlation coefficient (rho) of 85.1\%. Further, using difference of means (t-tests), we find that the differences between the 3 measures are not statistically significant, suggesting that the adjusted measures might not significantly change our results. We re-run all our main analyses using the adjusted measures. We find that our main results hold and our conclusions do not change across all measures of AIA. Specifically, we find that IFRS3A positively moderates the AIA-Tobin's Q relationship and the positive impact of IFRS3A on the AIA-Tobin's Q relationship is stronger in high IQ environments.

\section{Conclusion}

There is an open debate on the extent to which managerial discretion and latitude of action, particularly, with respect to financial reporting, can lead to more informative financial statements given the moral hazard that is often associated with such a discretion. This issue has been explored by prior research that examine discretion in accruals reporting and how that influences the quality of earnings estimates. Specifically, recent years have witnessed a growth in difficult-to-value intangibles coinciding with the growth in information technology (and related assets) and its role in business. Consequently, as evident in the 2008 amendments to IFRS 3, standard-setters have sought to improve the informativeness of intangible assets reported in financial statements. One of the key 
changes in the 2008 IFRS 3 amendment was to allow managers more discretion in recognizing identifiable intangible assets acquired in business combinations, specifically those which were previously unrecognized by the target company.

Besides responding to recent calls for further research into how IFRS 3 and the 2008 amendment to the standard affects the impact of business combinations on stakeholders, our paper offers new insights on how underlying IQ impacts on investors' perception of the relevance of financial statement information. Specifically, we advance three related hypotheses. Our first hypothesis explores whether recognized AIA are value relevant under IFRS 3 (i.e., from 2004 onwards). Related to this, our second hypothesis considers the 2008 IFRS 3 amendment and whether it increases the value relevance of AIA. We do not find support for our first hypothesis, but find evidence to support our second hypothesis. That is, AIA does not appear to be value relevant prior to the 2008 IFRS 3 amendment, but found to be value relevant after the 2008 IFRS 3 amendment. Given that the 2008 IFRS 3 amendment mainly allowed managers more discretion in identifying and valuing AIA, particularly those that were previously unrecognised by the target, we conjecture that this discretion allows managers to prepare more informative financial reports. Therefore, our evidence of the value relevance of AIA post-amendment, but not pre-amendment is not consistent with the argument that managers may use discretion to further their own interest (opportunistic behaviour). Indeed, we find a decline (rather than an increase) in reported AIA values after the amendment.

Nevertheless, we cannot rule out the risk of moral hazard with increased managerial discretion. We contend, therefore, that the benefit of additional managerial discretion in financial reporting is likely to be stronger in good underlying institutional environments. That is, checks and balances in the institutional environment may act as an added incentive for managers to refrain from opportunistic behaviour. Specifically, our third hypothesis explores the impact of underlying IQ on the value relevance of AIA post the 2008 IFRS amendment. Our results provide a caveat to our finding for our second hypothesis that AIA has become value relevant since the 2008 IFRS 3 amendment. Indeed, 
we find that our value relevance story only holds in environments with comparatively higher IQ, suggesting that the greater managerial discretion offered within the post-2008 IFRS amendment for recognizing previously unrecognized intangible assets in the acquired firm only renders AIA value relevant within strong institutional settings. Overall, our results suggest that the 2008 amendment has had a significant positive impact on the quality of reported AIA. Nonetheless, this improvement only effectively translates to more informative financial (AIA) information in the presence of strong institutions.

Our results have important regulatory and policy implications, as well as limitations. First, evidence that the 2008 IFRS 3 amendment that offers managers greater discretion enhances the value relevance of AIA implies that greater compliance and enforcement regarding the uniformity in implementation and application of the standard will be a step in the right direction, as this has the potential to enhance cross-border trade and investment. Second, the results indicate that AIA is more value relevant in high quality rather than low-quality institutional environments. This implies that the development and introduction of accounting standards and reforms, such as those relating to IFRS 3 should be pursued jointly with efforts to improve the broader institutional environment within which companies operate. In particular, national and global accounting standardsetters, such as the International Accounting Standards Board should be conscious that the extent to which accounting standards that are introduced are able to achieve their objectives is also contingent on the quality of the broader institutional factors, such as control of corruption, government effectiveness, political stability and absence of violence, regulatory quality, rule of law, and voice and accountability. Therefore, efforts at developing and introducing new accounting standards that are aimed at improving the quality of financial reporting and information should be accompanied by similar efforts at improving IQ, such as national governance.

Although our findings are robust and important, their limitations need to be explicitly acknowledged. For example and like all quantitative studies of this nature, our proxies for acquired intangible assets, price, firm value and IQ may or may not reflect practice. 
Similarly, although we have made every effort to address potential endogeneity problems, such as reverse causality and self-selection bias that may plague our findings, it is practically impossible to eliminate such problems completely. In this regard, future studies may offer new insights by conducting in-depth case studies by interviewing managers, practitioners, investors, accounting standard-setters and government officials regarding these issues. Further and as our study focuses on Africa, future studies can extend our findings by employing data relating to other continents, such as Asia and the Middle East. Finally, while we have suggested a simple strategy for extracting acquired intangibles from reported intangibles, there is scope for future studies to explore the accuracy of such a proxy vis-à-vis other proxies such as acquisition premiums. 


\section{References}

Abrahams, T. \& Sidhu, B. K. (1998). The role of R\&D capitalisations in firm valuation and perfor mance measurement. Australian Journal of Management, 23(2), 169-183.

AbuGhazaleh, N. M., Al-Hares, O. M. \& Roberts, C. (2011). Accounting discretion in goodwill impairments: Uk evidence. Journal of International Financial Management E5 Accounting, 22(3), 165-204.

Aktas, N., Croci, E. \& Petmezas, D. (2015). Is working capital management valueenhancing? Evidence from firm performance and investments. Journal of Corporate Finance, 30, 98-113.

Alali, F. A. \& Foote, P. S. (2012). The value relevance of international financial reporting standards: Empirical evidence in an emerging market. The international journal of accounting, 47(1), 85-108.

Amir, E. \& Lev, B. (1996). Value-relevance of nonfinancial information: The wireless communications industry. Journal of Accounting and Economics, 22(1-3), 3-30.

Barth, M. E. \& Clinch, G. (1998). Revalued financial, tangible, and intangible assets: Associations with share prices and non-market-based value estimates. Journal of Accounting Research, 36, 199-233.

Basu, S. \& Waymire, G. (2008). Has the importance of intangibles really grown? and if so, why? Accounting and Business Research, 38(3), 171-190.

Beattie, V. (2005). Moving the financial accounting research front forward: the uk contribution. The British Accounting Review, 37(1), 85-114.

Bertrand, M., Mehta, P. \& Mullainathan, S. (2002). Ferreting out tunneling: An application to indian business groups. The Quarterly Journal of Economics, 117(1), 121-148.

Bova, F. \& Pereira, R. (2012). The determinants and consequences of heterogeneous IFRS compliance levels following mandatory IFRS adoption: Evidence from a developing country. Journal of International Accounting Research, 11(1), 83-111.

Bowen, R. M., Rajgopal, S. \& Venkatachalam, M. (2008). Accounting discretion, cor- 
porate governance, and firm performance. Contemporary Accounting Research, 25(2), $351-405$.

Chambers, D., Jennings, R. \& Thompson, R. B. (2003). Managerial discretion and accounting for research and development costs. Journal of Accounting, Auditing $\&$ Finance, 18(1), 79-114.

Cleary, S. (1999). The relationship between firm investment and financial status. The Journal of Finance, 54(2), 673-692.

Collins, D. W., Maydew, E. L. \& Weiss, I. S. (1997). Changes in the value-relevance of earnings and book values over the past forty years. Journal of Accounting and Economics, 24(1), 39-67.

Dahmash, F. N., Durand, R. B. \& Watson, J. (2009). The value relevance and reliability of reported goodwill and identifiable intangible assets. The British Accounting Review, 41(2), 120-137.

d'Arcy, A. \& Tarca, A. (2018). Reviewing IFRS goodwill accounting research: Implementation effects and cross-country differences. The International Journal of Accounting, 53(3), 203-226.

Dechow, P., Ge, W. \& Schrand, C. (2010). Understanding earnings quality: A review of the proxies, their determinants and their consequences. Journal of Accounting and Economics, 50(2-3), 344-401.

Deloitte (2008). Business combinations and changes in ownership interests: A guide to the revised IFRS 3 and IAS 27. https://www.iasplus.com/en/binary/dttpubs/ 0807ifrs3guide.pdf. Last accessed on 30-10-2019.

Demski, J. S., Patell, J. M. \& Wolfson, M. A. (1984). Decentralized choice of monitoring systems. The Accounting Review, 59(1), 16.

Dong, J. \& Gou, Y.-n. (2010). Corporate governance structure, managerial discretion, and the r\&d investment in china. International Review of Economics \& Finance, 19(2), $180-188$.

Elamer, A. A., Ntim, C. G. \& Abdou, H. A. (2017). Islamic governance, national gov- 
ernance, and bank risk management and disclosure in mena countries. Business $\mathscr{E}$ Society (p. 0007650317746108).

Ellis, K. M., Lamont, B. T., Reus, T. H. \& Faifman, L. (2015). Mergers and acquisitions in africa: A review and an emerging research agenda. Africa Journal of Management, 1(2), $137-171$.

Eloff, A.-M. \& de Villiers, C. (2015). The value-relevance of goodwill reported under IFRS 3 versus IAS 22. South African Journal of Accounting Research, 29(2), 162-176.

Godfrey, J. \& Koh, P.-S. (2001). The relevance to firm valuation of capitalising intangible assets in total and by category. Australian Accounting Review, 11(24), 39-48.

Gong, J. J., Sophia, I. \& Wang, L. (2016). Changes in the value relevance of research and development expenses after IFRS adoption. Advances in accounting, 35, 49-61.

Goodwin, J. \& Ahmed, K. (2006). Longitudinal value relevance of earnings and intangible assets: Evidence from australian firms. Journal of International Accounting, Auditing and Taxation, 15(1), 72-91.

Hadani, M., Dahan, N. M. \& Doh, J. P. (2015). The ceo as chief political officer: Managerial discretion and corporate political activity. Journal of Business Research, 68(11), $2330-2337$.

Hamberg, M. \& Beisland, L.-A. (2014). Changes in the value relevance of goodwill accounting following the adoption of IFRS 3. Journal of International Accounting, Auditing and Taxation, 23(2), 59-73.

Hamberg, M., Paananen, M. \& Novak, J. (2011). The adoption of IFRS 3: The effects of managerial discretion and stock market reactions. European Accounting Review, 20(2), $263-288$

Hambrick, D. C. \& Abrahamson, E. (1995). Assessing managerial discretion across industries: A multimethod approach. Academy of Management Journal, 38(5), 1427-1441.

Han, B. H. \& Manry, D. (2004). The value-relevance of r\&d and advertising expenditures: Evidence from korea. The International Journal of Accounting, 39(2), 155-173.

Hasso, T. \& Duncan, K. (2013). Valuation of family firms: the limitations of accounting 
information. Australian Accounting Review, 23(2), 135-150.

Heckman, J. J. (1979). Sample selection bias as a specification error. Econometrica: Journal of the Econometric Society, 47(1), 153-161.

Higson, C. (1998). Goodwill. The British Accounting Review, 30(2), 141-158.

Holthausen, R. W. \& Watts, R. L. (2001). The relevance of the value-relevance literature for financial accounting standard setting. Journal of Accounting and Economics, 31(13), 3-75.

IASB (2008a). Business Combinations: International Financial Reporting Standard 3. International Accounting Standards Board.

IASB (2008b). Iasb issues standards on business combinations, goodwill and intangible assets. https://www.iasplus.com/en/binary/pressrel/2004pr06.pdf. Last accessed on 30-10-2019.

IFRS-Foundation (2019). Who uses IFRS standards? https://www.ifrs. org/use-around-the-world/use-of-ifrs-standards-by-jurisdiction/. Last accessed on 05-11-2019.

Joos, P. \& Lang, M. (1994). The effects of accounting diversity: Evidence from the european union. Journal of Accounting Research, 32, 141-168.

Kaufmann, D., Kraay, A. \& Mastruzzi, M. (2010). The worldwide governance indicators: Methodology and analytical issues (world bank policy research working paper no. 5430). Washington, DC: The World Bank.

Konara, P. \& Shirodkar, V. (2018). Regulatory institutional distance and mncs' subsidiary performance: climbing up vs. climbing down the institutional ladder. Journal of International Management, 24(4), 333-347.

Kothari, S. (2001). Capital markets research in accounting. Journal of Accounting and Economics, 31(1-3), 105-231.

Mergermarket (2016). Deal drivers africa 2016. https://www.mergermarket.com/info/ deal-drivers-africa-2016. Last accessed on 30-10-2019.

Morck, R., Shleifer, A. \& Vishny, R. W. (1990). Do managerial objectives drive bad 
acquisitions? The Journal of Finance, 45(1), 31-48.

Ntim, C. G., Opong, K. K. \& Danbolt, J. (2012). The relative value relevance of shareholder versus stakeholder corporate governance disclosure policy reforms in south africa. Corporate Governance: An International Review, 20(1), 84-105.

Ohlson, J. A. (1995). Earnings, book values, and dividends in equity valuation. Contemporary Accounting Research, 11(2), 661-687.

Oliveira, L., Rodrigues, L. L. \& Craig, R. (2010). Intangible assets and value relevance: Evidence from the portuguese stock exchange. The British Accounting Review, 42(4), $241-252$.

Perotti, P. \& Windisch, D. (2017). Managerial discretion in accruals and informational efficiency. Journal of Business Finance 83 Accounting, 44(3-4), 375-416.

Powell, S. (2003). Accounting for intangible assets: current requirements, key players and future directions. European accounting review, 12(4), 797-811.

PWC (2008). IFRS 3 (revised): Impact on earnings. the crucial Q\&A for decision-makers. https://www.pwc.ru/en/ifrs/assets/ifrs3r.pdf. Last accessed on 30-10-2019.

Samaha, K., Dahawy, K., Hussainey, K. \& Stapleton, P. (2012). The extent of corporate governance disclosure and its determinants in a developing market: The case of egypt. Advances in Accounting, 28(1), 168-178.

Schipper, K. (1989). Earnings management. Accounting horizons, 3(4), 91.

Shahwan, Y. (2004). The australian market perception of goodwill and identifiable intangibles. Journal of Applied Business Research (JABR), 20(4).

Sirén, C., Patel, P. C., Örtqvist, D. \& Wincent, J. (2018). Ceo burnout, managerial discretion, and firm performance: The role of ceo locus of control, structural power, and organizational factors. Long Range Planning, 51(6), 953-971.

Skinner, D. J. (2008). Accounting for intangibles-a critical review of policy recommendations. Accounting and Business Research, 38(3), 191-204.

Su, W. H. \& Wells, P. (2015). The association of identifiable intangible assets acquired and recognised in business acquisitions with postacquisition firm performance. Accounting 
E Finance, 55(4), 1171-1199.

Subramanyam, K. (1996). The pricing of discretionary accruals. Journal of Accounting and Economics, 22(1-3), 249-281.

Tan, H.-C. \& Jamal, K. (2006). Effect of accounting discretion on ability of managers to smooth earnings. Journal of Accounting and Public Policy, 25(5), 554-573.

Tucker, J. W. \& Zarowin, P. A. (2006). Does income smoothing improve earnings informativeness? The Accounting Review, 81(1), 251-270.

Tunyi, A. A. \& Ntim, C. G. (2016). Location advantages, governance quality, stock market development and firm characteristics as antecedents of african M\&As. Journal of International Management, 22(2), 147-167.

Tunyi, A. A., Ntim, C. G. \& Danbolt, J. (2019). Decoupling management inefficiency: Myopia, hyperopia and takeover likelihood. International Review of Financial Analysis, 62, 1-20.

Verrecchia, R. E. (1986). Managerial discretion in the choice among financial reporting alternatives. Journal of Accounting and Economics, 8(3), 175-195.

Verrecchia, R. E. (2001). Essays on disclosure. Journal of Accounting and Economics, 32(1-3), 97-180.

Wyatt, A. (2005). Accounting recognition of intangible assets: theory and evidence on economic determinants. The Accounting Review, 80(3), 967-1003. 


\section{Figures}

Figure 1: Acquired Intangible Assets and M\&A Activity by Year

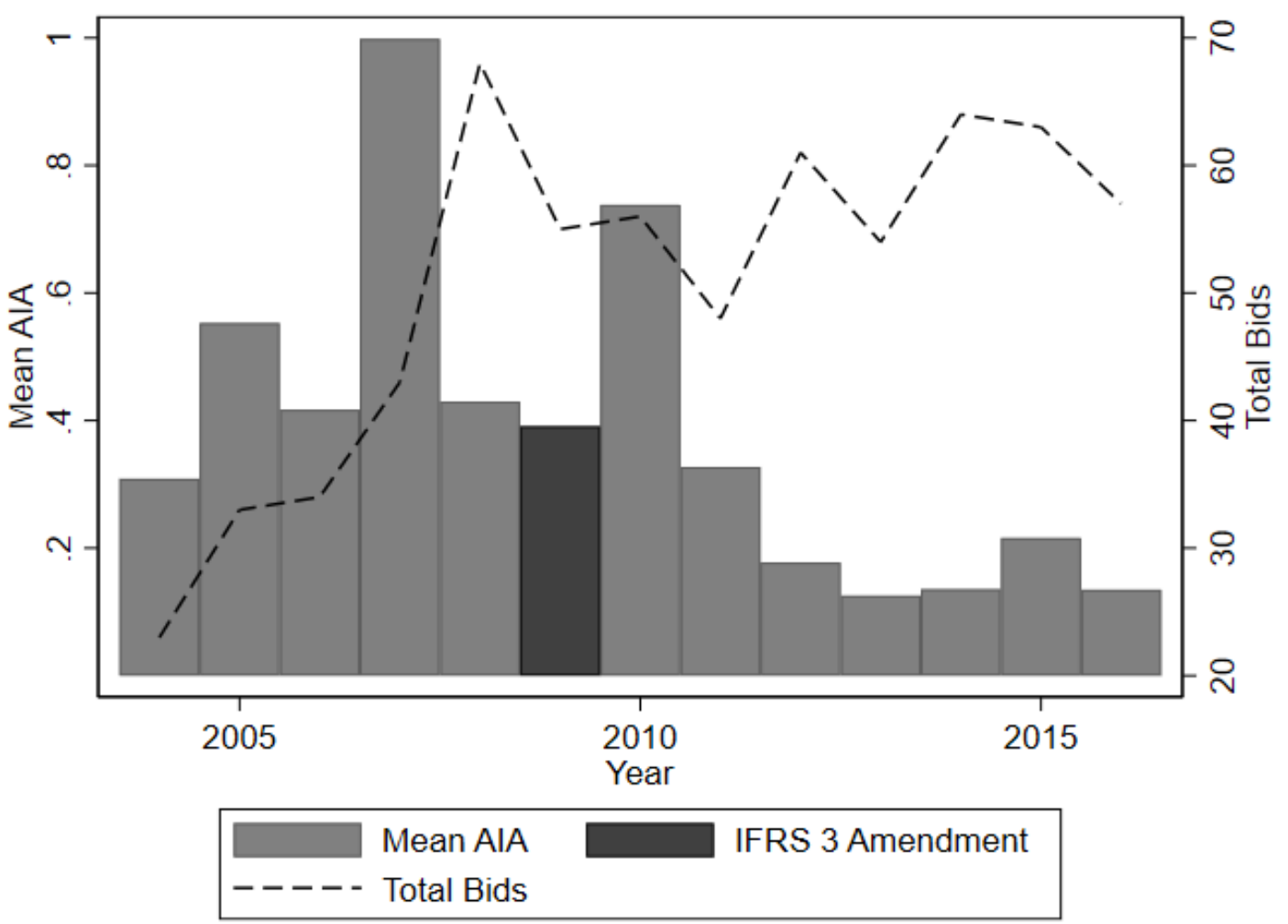




\section{Tables}

Table 1: Sample of acquirers by country

This table summarises acquisition activity across the countries in our sample. It presents the number of acquirers (bids), proportion of acquirers contributed by each country and each country's year of IFRS adoption. It also reports the average institutional quality (Mean IQ) computed as the mean of a country's World Governance Indicators (WGI) scores for the period 2004-2016.

\begin{tabular}{|c|c|c|c|c|}
\hline \multirow[b]{2}{*}{ Market } & \multicolumn{2}{|c|}{ Bid announcements } & \multirow{2}{*}{$\begin{array}{c}\text { IFRS Adoption } \\
\text { Year }\end{array}$} & \multirow{2}{*}{$\begin{array}{c}\text { Institutional quality } \\
\text { (Mean IQ) }\end{array}$} \\
\hline & Bids & Percent of sample & & \\
\hline Kenya & 18 & 2.99 & 2002 & -0.664 \\
\hline Mauritius & 12 & 1.99 & 2005 & 0.823 \\
\hline Morocco & 30 & 4.98 & 2004 & -0.317 \\
\hline Namibia & 1 & 0.17 & 2005 & 0.334 \\
\hline Nigeria & 24 & 3.98 & 2010 & -1.112 \\
\hline S.Africa & 517 & 85.74 & 2005 & 0.275 \\
\hline Zambia & 1 & 0.17 & 2005 & -0.258 \\
\hline Total & 603 & 100.00 & Mean & -0.113 \\
\hline
\end{tabular}


Table 2: Definition of variables

\begin{tabular}{|c|c|c|}
\hline Proxies & Variable & Description and construction \\
\hline Tobin's Q & Tobin's Q & $\begin{array}{l}\text { The sum of book value of debt and market value of equity } \\
\text { deflated by the book value of total assets. }\end{array}$ \\
\hline Price & Share price & $\begin{array}{l}\text { Market value of equity divided by opening period number } \\
\text { of shares. }\end{array}$ \\
\hline AIA & $\begin{array}{l}\text { Acquired intangible } \\
\text { assets }\end{array}$ & $\begin{array}{l}\text { The difference in an acquirer's total intangible assets (net } \\
\text { of impairments) pre- and post-acquisition, deflated by } \\
\text { opening period number of shares. }\end{array}$ \\
\hline AIA2 & $\begin{array}{l}\text { Acquired intangible } \\
\text { assets } 2\end{array}$ & $\begin{array}{l}\text { AIA less average increase in intangibles over the last two } \\
\text { years. }\end{array}$ \\
\hline AIA3 & $\begin{array}{l}\text { Acquired intangible } \\
\text { assets } 3\end{array}$ & $\begin{array}{l}\text { AIA less average increase in intangibles in previous years } \\
\text { starting from } 2004 \text {. }\end{array}$ \\
\hline AGW & Acquired goodwill & $\begin{array}{l}\text { The difference in an acquirer's total goodwill (net of im- } \\
\text { pairments) pre- and post acquisition, deflated by opening } \\
\text { period number of shares. }\end{array}$ \\
\hline OAIA & $\begin{array}{l}\text { Other acquired } \\
\text { intangible assets }\end{array}$ & The difference between AIA and AGW. \\
\hline IFRS3A & $\begin{array}{l}2008 \text { IFRS } 3 \\
\text { amendment }\end{array}$ & $\begin{array}{l}\text { An indicator variable which takes a value of } 1 \text { when year } \\
\text { is greater than } 2009 \text { and a value of zero when year is less } \\
\text { than } 2009 \text {. }\end{array}$ \\
\hline IQ & Institutional quality & $\begin{array}{l}\text { IQ is a composite measure of institutional quality de- } \\
\text { rived through Principal Component Analysis (PCA). In- } \\
\text { put variables include Worldwide Governance Indicators } \\
\text { (WGI); Control of Corruption index (CCI), Government } \\
\text { Effectiveness Index (GEI), Voice and Accountability In- } \\
\text { dex (VAI), Regulatory Quality Index (RQI), Political } \\
\text { Stability and Absence of Violence Index (PSAVI) and } \\
\text { Rule of Law Index (ROLI)(see, Kaufmann et al., 2010, } \\
\text { for details). }\end{array}$ \\
\hline High_IQ & $\begin{array}{l}\text { High institutional } \\
\text { quality }\end{array}$ & $\begin{array}{l}\text { Firm-years with IQ greater than the median IQ in each } \\
\text { year. }\end{array}$ \\
\hline Low_IQ & $\begin{array}{l}\text { Low institutional } \\
\text { quality }\end{array}$ & Firm-years with IQ less than the median IQ in each year. \\
\hline BVPS & Book value per share & $\begin{array}{l}\text { Book value of equity deflated by opening period number } \\
\text { of shares. }\end{array}$ \\
\hline EPS & Earnings per share & $\begin{array}{l}\text { Net earnings deflated by opening period number of } \\
\text { shares. }\end{array}$ \\
\hline LIQ & & The ratio of cash and short term securities to total assets. \\
\hline LEV & & The ratio of total debt to total assets. \\
\hline FCF & Free cash flow & $\begin{array}{l}\text { Net cash flow from operations less capital expenditures, } \\
\text { as a ratio of total assets. }\end{array}$ \\
\hline TANG & Tangible assets & $\begin{array}{l}\text { The ratio of property, plant and equipment to total as- } \\
\text { sets. }\end{array}$ \\
\hline SIZE & & Natural log of total assets. \\
\hline AGE & Firm age & The natural log of the number of years since listing. \\
\hline
\end{tabular}


Table 3: Descriptive statistics

Panel A of the table presents descriptive statistics for measures of acquired intangible assets (AIA), acquired goodwill (AGW) and other acquired intangible assets (OAIA) across different markets. Panel B of the table presents descriptive statistics on the cross-section of dependent and independent variables used in the study. Variables are fully defined in Table 2. The suffixes; "pre2009" and "post2009", indicate results for the period prior to and after the 2008 IFRS 3 amendment (i.e., 2004 to 2008 and 2010-2016), respectively.

\begin{tabular}{|c|c|c|c|c|c|c|c|c|}
\hline \multicolumn{9}{|c|}{ Panel A: Acquired intangible assets } \\
\hline Market & Mean & p25 & p50 & p75 & Mean & Median & Mean & Median \\
\hline Kenya & 0.257 & -0.001 & 0.003 & 0.029 & 0.200 & 0.000 & 0.058 & 0.001 \\
\hline Mauritius & 1.010 & 0.016 & 0.022 & 0.032 & 0.009 & 0.002 & 1.001 & 0.010 \\
\hline Morocco & 3.059 & 0.074 & 0.574 & 4.521 & 2.096 & 0.096 & 0.963 & 0.087 \\
\hline Namibia & 0.022 & 0.022 & 0.022 & 0.022 & 0.034 & 0.034 & -0.012 & -0.012 \\
\hline Nigeria & 0.006 & 0.000 & 0.001 & 0.007 & 0.005 & 0.000 & 0.001 & 0.000 \\
\hline S.Africa & 0.202 & -0.005 & 0.016 & 0.183 & 0.134 & 0.003 & 0.098 & 0.000 \\
\hline Total & 0.357 & -0.002 & 0.016 & 0.204 & 0.234 & 0.002 & 0.149 & 0.000 \\
\hline
\end{tabular}

Panel B: Dependent and independent variables

\begin{tabular}{lccccc}
\hline & N & Mean & p25 & p50 & p75 \\
AIA_pre2009 & 140 & 0.550 & 0.000 & 0.042 & 0.387 \\
AIA_2009 & 51 & 0.377 & -0.001 & 0.046 & 0.260 \\
AIA_post2009 & 330 & 0.272 & -0.007 & 0.005 & 0.156 \\
AIA_All & 521 & 0.357 & -0.002 & 0.016 & 0.204 \\
AGW_pre2009 & 140 & 0.435 & 0.000 & 0.026 & 0.207 \\
AGW_2009 & 51 & 0.067 & 0.000 & 0.009 & 0.114 \\
AGW_post2009 & 330 & 0.178 & -0.006 & 0.000 & 0.046 \\
AGW_All & 521 & 0.236 & -0.001 & 0.003 & 0.082 \\
OAIA_pre2009 & 140 & 0.194 & -0.012 & 0.000 & 0.077 \\
OAIA_2009 & 51 & 0.313 & -0.025 & 0.000 & 0.113 \\
OAIA_post2009 & 330 & 0.105 & -0.008 & 0.001 & 0.064 \\
OAIA_All & 521 & 0.149 & -0.011 & 0.000 & 0.068 \\
Price & 521 & 10.305 & 0.410 & 2.170 & 8.990 \\
Tobin's Q & 521 & 1.555 & 1.040 & 1.296 & 1.792 \\
BVPS (Book value per share) & 521 & 19.792 & 0.509 & 1.897 & 8.115 \\
EPS (Earnings per share) & 521 & 0.673 & 0.027 & 0.168 & 0.691 \\
LIQ (Liquidity) & 521 & 0.100 & 0.027 & 0.065 & 0.142 \\
LEV (Leverage) & 521 & 0.211 & 0.088 & 0.182 & 0.303 \\
FCF (Free cash flow) & 513 & 0.022 & -0.012 & 0.026 & 0.070 \\
TANG (Tangible assets) & 519 & 0.302 & 0.050 & 0.194 & 0.513 \\
SIZE (Firm size) & 521 & 20.374 & 18.715 & 20.331 & 21.843 \\
AGE (Firm age) & 521 & 2.392 & 1.946 & 2.708 & 3.045 \\
\hline \hline
\end{tabular}




\section{Table 4: Acquired intangibles and firm value}

This table illustrates the effect of the IFRS 3 amendment (IFRS3A) on the value relevance of acquired goodwill (AGW) and other acquired intangible assets (OAIA). Columns 1 and 4 explore the relationship between AGW, OAIA and firm value over the full period (2004-2016). Columns 2, 3,4 and 5 test the extent to which IFRS3A moderates the value relevance of AGW and OAIA. In Columns 2 and 5 [3 and 6], AGW (and consequently, OAIA) is derived from equation 2 [2a]. All models control for firm characteristics, industry and year fixed-effects. All variables are fully defined in Table 2. We conduct two-tailed tests of significance. $* * *, * *$ and $*$ indicate statistical significance at the $1 \%(p$-value $<0.01), 5 \%(0.01 \leq p$-value $<0.05)$ and $10 \%(0.05 \leq p$-value $<0.1)$ levels, respectively.

\begin{tabular}{|c|c|c|c|c|c|c|}
\hline \multirow[b]{2}{*}{ Model } & \multicolumn{3}{|c|}{ Tobin's Q } & \multicolumn{3}{|c|}{ Price } \\
\hline & (1) & (2) & $(3)$ & (4) & $(5)$ & (6) \\
\hline \multirow[t]{2}{*}{ AGW } & 0.003 & -0.029 & -0.026 & 0.563 & 1.287 & 1.234 \\
\hline & $(0.844)$ & $(0.260)$ & $(0.305)$ & $(0.846)$ & $(0.140)$ & $(0.168)$ \\
\hline \multirow[t]{2}{*}{ OAIA } & 0.020 & 0.009 & 0.007 & -1.088 & $-5.549 * * *$ & $-5.479 * * *$ \\
\hline & $(0.623)$ & $(0.858)$ & $(0.891)$ & $(0.781)$ & $(0.007)$ & $(0.007)$ \\
\hline \multirow[t]{2}{*}{ IFRS3A } & & -0.023 & -0.031 & & 52.736 & 53.091 \\
\hline & & $(0.862)$ & $(0.811)$ & & $(0.123)$ & $(0.122)$ \\
\hline \multirow[t]{2}{*}{ IFRS3A*AGW } & & $0.102^{* *}$ & $0.104^{* *}$ & & $3.467^{* *}$ & $4.129^{* *}$ \\
\hline & & $(0.024)$ & $(0.028)$ & & $(0.035)$ & $(0.012)$ \\
\hline \multirow[t]{2}{*}{ IFRS3A*OAIA } & & $0.168^{*}$ & $0.171^{*}$ & & $10.322^{* * *}$ & $10.318^{* * *}$ \\
\hline & & $(0.087)$ & $(0.082)$ & & $(0.000)$ & $(0.000)$ \\
\hline \multirow[t]{2}{*}{ LIQ } & 0.434 & 0.454 & 0.456 & & & \\
\hline & $(0.399)$ & $(0.376)$ & $(0.373)$ & & & \\
\hline \multirow[t]{2}{*}{ LEV } & 0.372 & 0.354 & 0.354 & & & \\
\hline & $(0.361)$ & $(0.386)$ & $(0.387)$ & & & \\
\hline \multirow[t]{2}{*}{$\mathrm{FCF}$} & $2.014^{* * *}$ & $2.088^{* * *}$ & $2.093^{* * *}$ & & & \\
\hline & $(0.002)$ & $(0.002)$ & $(0.002)$ & & & \\
\hline \multirow{2}{*}{ TANG } & -0.097 & -0.047 & -0.044 & & & \\
\hline & $(0.726)$ & $(0.867)$ & $(0.877)$ & & & \\
\hline \multirow{2}{*}{ SIZE } & -0.007 & -0.011 & -0.011 & & & \\
\hline & $(0.823)$ & $(0.731)$ & $(0.723)$ & & & \\
\hline \multirow[t]{2}{*}{ AGE } & 0.052 & 0.054 & 0.054 & & & \\
\hline & $(0.295)$ & $(0.277)$ & $(0.277)$ & & & \\
\hline \multirow[t]{2}{*}{ BVPS } & & & & 0.091 & $0.201^{* * *}$ & $0.202^{* * *}$ \\
\hline & & & & $(0.116)$ & $(0.000)$ & $(0.000)$ \\
\hline \multirow[t]{2}{*}{ EPS } & & & & $11.619^{* *}$ & $5.815 * * *$ & $5.747^{* * *}$ \\
\hline & & & & $(0.024)$ & $(0.000)$ & $(0.000)$ \\
\hline \multirow{2}{*}{ Constant } & $0.959^{* *}$ & $0.866^{*}$ & $0.882^{*}$ & $-46.367^{* *}$ & -50.102 & -54.396 \\
\hline & $(0.049)$ & $(0.082)$ & $(0.080)$ & $(0.024)$ & $(0.289)$ & $(0.253)$ \\
\hline Observations & 511 & 511 & 511 & 521 & 521 & 521 \\
\hline Firms & 252 & 252 & 252 & 259 & 259 & 259 \\
\hline Industry FE & YES & YES & YES & YES & YES & YES \\
\hline Year FE & YES & YES & YES & YES & YES & YES \\
\hline
\end{tabular}




\section{Table 5: Principal component analyses}

The table illustrates the derivation measures of institutional quality (IQ) from World Governance Indicators (WGI) (Kaufmann et al., 2010). Panel A presents pairwise correlation coefficients of WGI for the countries in our sample. Panel B presents output from principal component analysis (PCA) aimed at reducing WGIs into factors that can be used for subsequent analyses. Panel C presents mean values for measures of IQ for African countries with business combinations. PCA_IQ refers to the first component from PCA analysis. KMO is the Kaiser-Meyer-Olkin measure of sampling adequacy.

\begin{tabular}{lccccc}
\hline \multicolumn{5}{c}{ Panel A: Correlation statistics } \\
CCI & GEI & VAI & RQI & ROLI \\
GEI & $0.923^{* * *}$ & & & & \\
VAI & $0.794^{* * *}$ & $0.847^{* * *}$ & & & \\
RQI & $0.905^{* * *}$ & $0.968^{* * *}$ & $0.850^{* * *}$ & & \\
ROLI & $0.891^{* * *}$ & $0.942^{* * *}$ & $0.805^{* * *}$ & $0.899^{* * *}$ & \\
PSAVI & $0.878^{* * *}$ & $0.888^{* * *}$ & $0.743^{* * *}$ & $0.846^{* * *}$ & $0.937^{* * *}$ \\
\hline
\end{tabular}

Panel B: The PCA statistics

\begin{tabular}{lccccccc} 
Variable & Comp1 & Comp2 & Comp3 & Comp4 & Comp5 & Comp6 & KMO \\
CCI & 0.410 & -0.145 & -0.429 & 0.766 & -0.189 & 0.066 & 0.957 \\
GEI & 0.423 & 0.010 & -0.271 & -0.329 & -0.085 & -0.795 & 0.843 \\
VAI & 0.382 & 0.795 & 0.431 & 0.192 & 0.017 & -0.015 & 0.977 \\
RQI & 0.416 & 0.154 & -0.472 & -0.400 & 0.406 & 0.505 & 0.870 \\
ROLI & 0.416 & -0.262 & 0.290 & -0.308 & -0.690 & 0.321 & 0.865 \\
PSAVI & 0.402 & -0.505 & 0.500 & 0.114 & 0.561 & -0.070 & 0.881 \\
Eigenvalue & 5.377 & 0.293 & 0.153 & 0.104 & 0.051 & 0.022 & \\
Difference & 5.085 & 0.140 & 0.049 & 0.053 & 0.029 & - & \\
Proportion & 0.896 & 0.049 & 0.026 & 0.017 & 0.009 & 0.004 & \\
Cumulative & 0.896 & 0.945 & 0.971 & 0.988 & 0.996 & 1.000 & \\
KMO (overall) & & \multicolumn{7}{c}{} & & & 0.893 \\
\hline \multicolumn{7}{r}{ Panel C: } & Average of measures of institutional quality across countries \\
Market & CCI & GEI & VAI & RQI & ROLI & PSAVI & PCA_IQ \\
Kenya & -0.985 & -0.49 & -0.219 & -0.247 & -0.771 & -1.271 & -3.216 \\
Mauritius & 0.389 & 0.927 & 0.862 & 0.967 & 0.904 & 0.886 & 3.696 \\
Morocco & -0.311 & -0.12 & -0.684 & -0.16 & -0.195 & -0.433 & -1.472 \\
Namibia & 0.331 & 0.14 & 0.463 & 0.02 & 0.211 & 0.841 & 1.223 \\
Nigeria & -1.148 & -1.065 & -0.576 & -0.772 & -1.088 & -2.024 & -5.249 \\
S.Africa & 0.124 & 0.411 & 0.61 & 0.417 & 0.129 & -0.044 & 1.084 \\
Zambia & -0.362 & -0.592 & -0.157 & -0.473 & -0.339 & 0.374 & -1.524 \\
\hline
\end{tabular}




\section{Table 6: Institutional quality and value relevance of acquired intangibles}

The table illustrates the impact of country-level institutional quality (IQ) on the relationship between acquired intangible assets and firm value (Tobin's Q and Price), pre- and post-the 2008 IFRS 3 amendment. It shows regression results on a three-way interaction effect between measures of acquired goodwill (AGW), the 2008 IFRS 3 amendment (IFRS3A), institutional quality (IQ) and measures of firm value (Tobin's Q and Price). In Columns 1 and 3, IQ is measured using an indicator variable which takes a value of 1 , for acquirers in high IQ environments and a value of 0 , otherwise. In Columns 2 and 4, IQ is measured as a continuous variable derived from principal component analysis as explained in Table 2. Control variables (LIQ, LEV, FCF, TANG, SIZE, AGE) included in Columns 1 and 2 are suppressed to save space. Marginal effects report the impact of AGW and OAIA on firm value at various levels of IQ (high or High_IQ $=1$ versus low or High_IQ=0) both pre- and post-the amendment. All models control for industry and year fixed-effects. All variables are fully defined in Table 2. We conduct two-tailed tests of significance. ${ }^{* * *},{ }^{* *}$ and $*$ indicate statistical significance at the $1 \%(p$-value $<0.01)$, $5 \%(0.01 \leq p$-value $<0.05)$ and $10 \%(0.05 \leq p$-value $<0.1)$ levels, respectively.

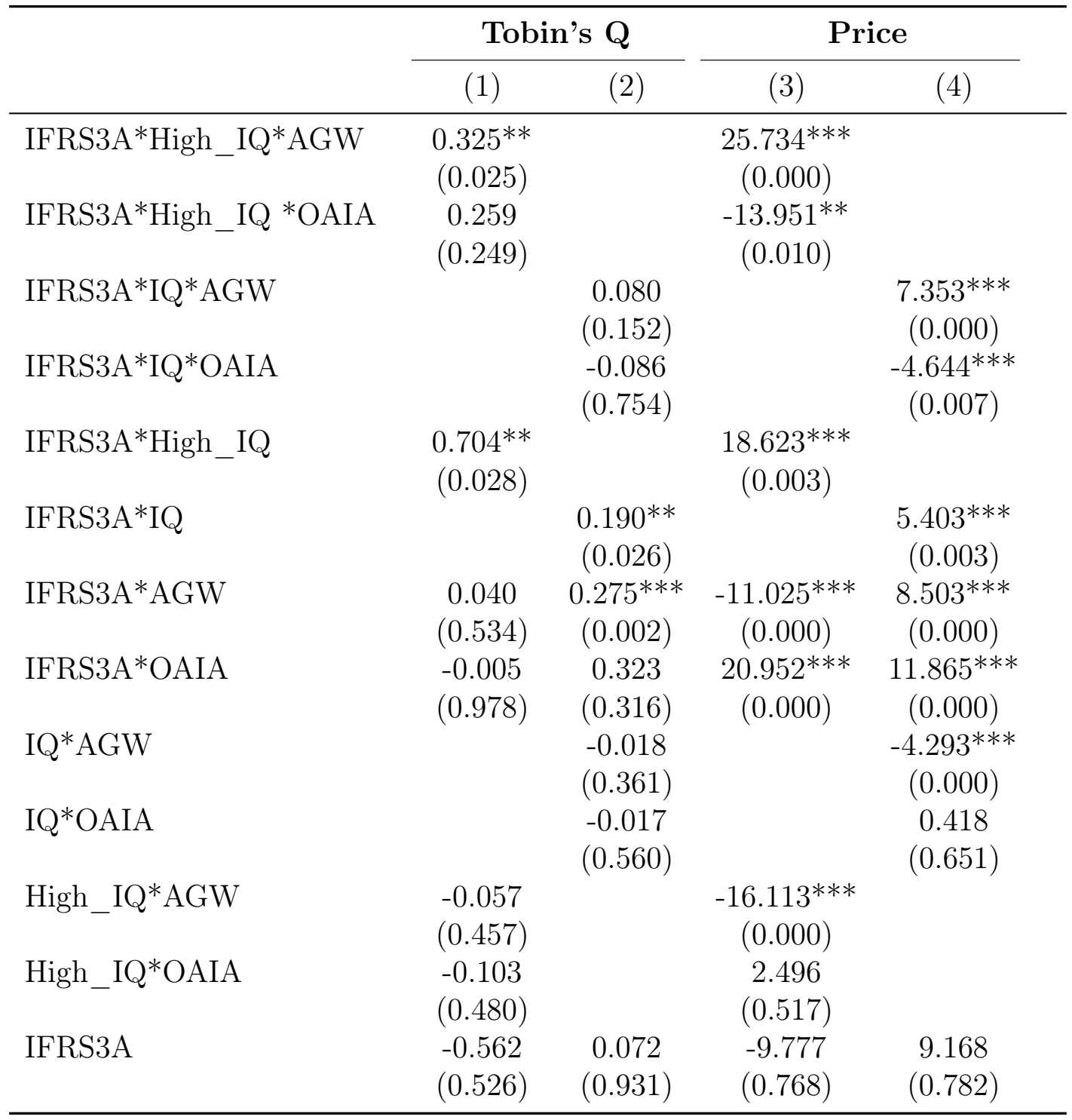


Table 6: - continued

\begin{tabular}{|c|c|c|c|c|}
\hline High_IQ & $\begin{array}{c}-0.649 * * \\
(0.030)\end{array}$ & & $\begin{array}{c}-36.109^{* * *} \\
(0.000)\end{array}$ & \\
\hline IQ & & $\begin{array}{c}-0.176^{* *} \\
(0.026)\end{array}$ & & $\begin{array}{c}-7.200^{* * *} \\
(0.000)\end{array}$ \\
\hline AGW & $\begin{array}{l}-0.041 \\
(0.302)\end{array}$ & $\begin{array}{c}-0.098^{*} \\
(0.069)\end{array}$ & $\begin{array}{c}12.236^{* * *} \\
(0.000)\end{array}$ & $\begin{array}{l}-1.148 \\
(0.159)\end{array}$ \\
\hline OAIA & $\begin{array}{l}-0.048 \\
(0.544)\end{array}$ & $\begin{array}{l}-0.093 \\
(0.240)\end{array}$ & $\begin{array}{c}-7.677^{* * *} \\
(0.006)\end{array}$ & $\begin{array}{c}-5.185^{* *} \\
(0.012)\end{array}$ \\
\hline BVPS & & & $\begin{array}{c}0.087^{* * * *} \\
(0.000)\end{array}$ & $\begin{array}{c}0.085^{* * *} \\
(0.000)\end{array}$ \\
\hline EPS & & & $\begin{array}{c}4.607^{* * *} \\
(0.000)\end{array}$ & $\begin{array}{c}4.573^{* * *} \\
(0.000)\end{array}$ \\
\hline Controls & YES & YES & $\mathrm{NO}$ & $\mathrm{NO}$ \\
\hline Constant & & $\begin{array}{c}0.886 \\
(0.477)\end{array}$ & $\begin{array}{l}24.366 \\
(0.599)\end{array}$ & $\begin{array}{l}-9.933 \\
(0.828)\end{array}$ \\
\hline Observations & 519 & 511 & 521 & 521 \\
\hline Firms & 258 & 252 & 259 & 259 \\
\hline Industry FE & YES & YES & YES & YES \\
\hline Year FE & YES & YES & YES & YES \\
\hline Marginal effects & \multicolumn{2}{|c|}{ Tobin's Q } & \multicolumn{2}{|c|}{ Price } \\
\hline & $\begin{array}{l}\mathrm{AGW} \\
(1)\end{array}$ & $\begin{array}{c}\text { OAIA } \\
(2)\end{array}$ & $\begin{array}{c}\text { AGW } \\
(3)\end{array}$ & $\begin{array}{c}\text { OAIA } \\
(4)\end{array}$ \\
\hline IFRS3A $=0$, High_IQ $=0$ & $\begin{array}{l}-0.041 \\
(0.302)\end{array}$ & $\begin{array}{l}-0.048 \\
(0.544)\end{array}$ & $\begin{array}{c}12.236^{* * *} \\
(0.000)\end{array}$ & $\begin{array}{c}-7.677^{* * *} \\
(0.006)\end{array}$ \\
\hline $\mathrm{IFRS} 3 \mathrm{~A}=0, \mathrm{High}_{-} \mathrm{IQ}=1$ & $\begin{array}{l}-0.097 \\
(0.141)\end{array}$ & $\begin{array}{l}-0.151 \\
(0.225)\end{array}$ & $\begin{array}{c}-3.877^{* * *} \\
(0.000)\end{array}$ & $\begin{array}{c}-5.181^{*} \\
(0.050)\end{array}$ \\
\hline $\mathrm{IFRS} 3 \mathrm{~A}=1, \mathrm{High}_{-} \mathrm{IQ}=0$ & $\begin{array}{l}-0.001 \\
(0.991)\end{array}$ & $\begin{array}{l}-0.053 \\
(0.720)\end{array}$ & $\begin{array}{c}1.211 \\
(0.516)\end{array}$ & $\begin{array}{c}13.274^{* * *} \\
(0.001)\end{array}$ \\
\hline IFRS3A $=1$, High_IQ $=1$ & $\begin{array}{c}0.267^{* *} \\
(0.024)\end{array}$ & $\begin{array}{c}0.104 \\
(0.353)\end{array}$ & $\begin{array}{c}10.832^{* * *} \\
(0.000)\end{array}$ & $\begin{array}{c}1.820 \\
(0.282)\end{array}$ \\
\hline
\end{tabular}




\section{Table 7: AIA and IFRS 3 amendment in high and low IQ environments}

The table explores the impact of country-level institutional quality (IQ) on the relationship between acquired intangible assets (AIA) and firm value (Tobin's Q and Price), pre- and post-the 2008 IFRS 3 amendment. Columns 1 and 2 explore the moderating effect of the 2008 IFRS 3 amendment on the relationship between of acquired goodwill (AGW), other acquired intangible assets (OAIA) and firm value (Tobin's Q and Price) in low IQ environments. Columns 3 and 4 explore the same relationships in high IQ environments. The difference between the coefficients reported in Columns 1 and 3, as well as Columns 2 and 4, is tested for significance in Columns 5 and 6 . All models control for industry and year fixed-effects, as well as, firm characteristics. Control variables (LIQ, LEV, FCF, TANG, SIZE, AGE) included in Columns 1, 3 and 5 are suppressed to save space. All variables are fully defined in Table 2. We conduct two-tailed tests of significance. $* * *, * *$ and $*$ indicate statistical significance at the $1 \%$ $(p$-value $<0.01), 5 \%(0.01 \leq p$-value $<0.05)$ and $10 \%(0.05 \leq p$-value $<0.1)$ levels, respectively.

\begin{tabular}{|c|c|c|c|c|c|c|}
\hline & \multicolumn{2}{|c|}{ Low IQ } & \multicolumn{2}{|c|}{ High IQ } & \multicolumn{2}{|c|}{ Difference } \\
\hline & $\begin{array}{c}\text { Tobin's Q } \\
\text { (1) }\end{array}$ & $\begin{array}{l}\text { Price } \\
(2)\end{array}$ & $\begin{array}{c}\text { Tobin's Q } \\
(3)\end{array}$ & $\begin{array}{l}\text { Price } \\
(4)\end{array}$ & $\begin{array}{l}(1)-(3) \\
(5)\end{array}$ & $\begin{array}{l}(2)-(4) \\
(6)\end{array}$ \\
\hline IFRS3A*AGW & $\begin{array}{c}0.061 \\
(0.557)\end{array}$ & $\begin{array}{c}-21.223^{* * *} \\
(0.000)\end{array}$ & $\begin{array}{c}0.362^{* * * *} \\
(0.005)\end{array}$ & $\begin{array}{c}8.829^{* * *} \\
(0.000)\end{array}$ & $\begin{array}{l}-0.301 \\
(0.206)\end{array}$ & $\begin{array}{c}-30.052^{* *} \\
(0.012)\end{array}$ \\
\hline IFRS3A*OAIA & $\begin{array}{c}0.013 \\
(0.895)\end{array}$ & $\begin{array}{c}16.215^{* * *} \\
(0.000)\end{array}$ & $\begin{array}{l}0.297^{*} \\
(0.061)\end{array}$ & $\begin{array}{l}4.704^{* *} \\
(0.037)\end{array}$ & $\begin{array}{l}-0.284 \\
(0.181)\end{array}$ & $\begin{array}{l}11.511 \\
(0.103)\end{array}$ \\
\hline AGW & $\begin{array}{c}0.029 \\
(0.438)\end{array}$ & $\begin{array}{l}4.625^{*} \\
(0.081)\end{array}$ & $\begin{array}{l}-0.107 \\
(0.103)\end{array}$ & $\begin{array}{l}-1.295 \\
(0.208)\end{array}$ & $\begin{array}{c}0.136 \\
(0.251)\end{array}$ & $\begin{array}{c}5.920 \\
(0.119)\end{array}$ \\
\hline IFRS3A & $\begin{array}{c}-1.934^{* * *} \\
(0.000)\end{array}$ & $\begin{array}{l}-98.688 \\
(0.209)\end{array}$ & $\begin{array}{c}0.130 \\
(0.882)\end{array}$ & $\begin{array}{c}0.688 \\
(0.952)\end{array}$ & $\begin{array}{c}-2.064^{* * * *} \\
(0.007)\end{array}$ & $\begin{array}{c}-99.376^{* *} \\
(0.031)\end{array}$ \\
\hline OAIA & $\begin{array}{c}-0.099^{* *} \\
(0.021)\end{array}$ & $\begin{array}{c}-8.834^{* *} \\
(0.013)\end{array}$ & $\begin{array}{l}-0.174 \\
(0.166)\end{array}$ & $\begin{array}{l}-1.003 \\
(0.554)\end{array}$ & $\begin{array}{c}0.075 \\
(0.375)\end{array}$ & $\begin{array}{l}-7.830 \\
(0.263)\end{array}$ \\
\hline BVPS & & $\begin{array}{l}-0.010 \\
(0.824)\end{array}$ & & $\begin{array}{c}0.056^{* * *} \\
(0.003)\end{array}$ & & $\begin{array}{l}-0.066 \\
(0.313)\end{array}$ \\
\hline EPS & & $\begin{array}{c}13.741^{* * *} \\
(0.000)\end{array}$ & & $\begin{array}{c}4.350^{* * * *} \\
(0.000)\end{array}$ & & $\begin{array}{c}9.391 \\
(0.164)\end{array}$ \\
\hline Controls & YES & $\mathrm{NO}$ & YES & $\mathrm{NO}$ & YES & $\mathrm{NO}$ \\
\hline Constant & $\begin{array}{c}6.029^{* * * *} \\
(0.000)\end{array}$ & $\begin{array}{c}392.849^{* * *} \\
(0.001)\end{array}$ & $\begin{array}{c}0.691 \\
(0.580)\end{array}$ & $\begin{array}{c}0.146 \\
(0.992)\end{array}$ & & \\
\hline Observations & 57 & 57 & 459 & 464 & & \\
\hline Firms & 40 & 40 & 215 & 219 & & \\
\hline Industry FE & YES & YES & YES & YES & YES & YES \\
\hline Year FE & YES & YES & YES & YES & YES & YES \\
\hline
\end{tabular}

